University of San Diego

Digital USD

2016

\title{
Clients as Voting Board Members: A Mixed Methods Examination of San Diego County Nonprofit Human Services Organizations
}

\author{
Elaine Marie Lewis \\ University of San Diego
}

Follow this and additional works at: https://digital.sandiego.edu/dissertations

Part of the Nonprofit Administration and Management Commons, Organizational Behavior and Theory Commons, and the Public Policy Commons

\section{Digital USD Citation}

Lewis, Elaine Marie, "Clients as Voting Board Members: A Mixed Methods Examination of San Diego County Nonprofit Human Services Organizations" (2016). Dissertations. 48.

https://digital.sandiego.edu/dissertations/48 Digital USD. It has been accepted for inclusion in Dissertations by an authorized administrator of Digital USD. For more information, please contact digital@sandiego.edu. 
CLIENTS AS VOTING BOARD MEMBERS: A MIXED METHODS EXAMINATION OF SAN DIEGO COUNTY NONPROFIT HUMAN SERVICES ORGANIZATIONS

Elaine Marie Lewis

A dissertation submitted in partial fulfillment

of the requirements for the degree of

Doctor of Philosophy

August 26, 2016

Dissertation Committee

Robert Donmoyer, Ph.D.

Fred J. Galloway, Ed.D.

Mary McDonald, Ph.D.

University of San Diego 
Copyright page 


\title{
UNIVERSITY OF SAN DIEGO SCHOOL OF LEADERSHIP AND EDUCATION SCIENCES
}

\author{
CANDIDATE'S NAME: Elaine Marie Lewis
}

TITLE OF

DISSERTATION: CLIENTS AS VOTING BOARD MEMBERS: A MIXED METHODS EXAMINATION OF SAN DIEGO COUNTY

NONPROFIT HUMAN SERVICES ORGANIZATION

APPROVAL:

\begin{tabular}{ll}
\hline Robert Donmoyer, Ph,D. & Chair \\
\hline Fred J. Galloway, Ed.D. & Member \\
\hline Mary B. Mctłonald , Ph.D. & Member
\end{tabular}

DATE: June 23, 2016 


\begin{abstract}
The literature suggests that thoughtful board composition generates more strategic and thoughtful policymaking. This study examined one aspect of board composition that is frequently cited as a source of more strategic and thoughtful policymaking: clients as voting members.

This study used descriptive and inferential statistics to examine the prevalence of, and the factors associated with clients participating as board members of human services nonprofit organizations in San Diego County. Through a review of the most recent 12 months of board meeting notes, this study also explored the level of participation of two clients on the board of directors of one organization.

The work was accomplished in two phases. The National Taxonomy of Exempt Entities Core Codes (NTEE-CC) was used to identify organizations in the human services category. During the first phase, 275 human services organizations in San Diego County were invited to have a representative participate in a survey, either electronically or by telephone. Sixty-one organizations participated in the survey resulting in a response rate of $22 \%$. A nonresponse-bias test suggested that there was no significant difference between the responding organizations and the population.

Of the 61 respondents, 14 indicated they had at least one client on their organization's board of directors. The study also explored client involvement in other potential decision-making activities including serving on advisory committees, volunteering as part of a work group, completing fact-finding surveys, and holding membership.
\end{abstract}


Binomial logistic regression analysis was used to identify demographic variables and other organizational characteristics associated with having clients on boards. Among other things, this analysis revealed that $71 \%$ of organizations with clients on boards were classified as NTEE-CC subsectors P80-89, i.e., Centers to Support the Independence of Specific Populations.

Phase II of this study entailed an examination of the board meeting notes of one organization with two clients on its board of directors. The meeting notes indicated that client board members participated in meeting activities at the same level as non-client board members did.

This study is an initial attempt to move beyond normative discussions of clients on nonprofit organizations' boards. Additional empirical work needs to be done.

Keywords: nonprofit, decision-making, clients, boards of directors, governance, membership, human services 


\section{DEDICATION}

Dedicated to Mrs. Cliff and Alva L. Link. Mrs. Cliff was my fifth grade teacher, "Good enough." was never enough. Alva showed me the true meaning of perseverance and determination against incredible odds. 


\section{ACKNOWLEDGEMENTS}

This body of work brings to close an incredible journey. I consider myself fortunate to have been able to travel the path so skillfully mapped out by the faculty and staff at the University of San Diego School of Leadership and Education Science. This

was one of the longest and clearly one of my most treasured journeys. Moving forward, I look forward to many shorter adventures armed with the knowledge I have gained.

I have been fortunate to have had a "Dream Team" committee. Without their steadfast support and encouragement, my journey would have ended prematurely.

Dr. Robert Donmoyer, has tolerated my eccentricities and at times might have even encouraged me to push the limits further. My memories of sharing "Moose Nose" soup with "Sweeping Horse" in Canada, to the many hours working at his coffee house office will always be remembered fondly. I would be remiss if I did not thank June Yennie-Donmoyer for her friendship, encouragement, and wonderful hospitality.

If it wasn't for Dr. Fred Galloway, I would still be looking a cicadas as just another insect. He was always there to help me put my wheels back on the track. The technical and practical skills I developed in Dr. Galloway's classes will most certainly serve me well in the future.

Dr. Mary McDonald provided me with many opportunities to stretch my analytical skills in practical ways. I am so grateful she invited me to work with her in her research. Many of the skills I learned from working with Dr. McDonald were extremely valuable in my own research.

Thanks to my "grown-up" friends Cindy Traxler and Patricia Wesley for their continued support and cheer leading. Dr. Cordeiro not only offered her support and 
encouragement but also set a standard of excellence that I will continue to be inspired by in the future. Thank you to Melanie Hitchcock Ph.D. and Alma Ortega for the many hours spent in the library basement, sometimes not so gently prompting each other whenever we engaged in work avoidance. To Dr. Roberts, "BOOM.” Dr. Castillo for her unending optimism and thoughtfulness. Many thanks to everyone in the Caster Center. Special thanks to Pat Libby and Mike Eichler for encouraging me to return to school after a 17 year absence, and for supporting me academically and personally.

I am forever indebted to everyone in the Leadership office. Beth Garofolo, as my advisor, Dr. Getz, and Dr. Nahavandi for their thoughtful support. Thank you to Heather Gibb for her encouragement and support, she always seemed to have whatever was needed, supplies, answers, sarcasm, and humor. There are literally hundreds of other people who provided me with support and encouragement.

I am extremely fortunate to have had parents the encouraged and supported me. They may not be on this earth but they were with me every step of the way. Many thanks to my nieces and nephews for tolerating my absence. I will never be able to make-up for time lost, but I will spend the rest of my life trying.

Finally, I wish to thank all the people I had the honor to serve, for allowing me into their lives. Over the course of my career, they gave me more than I will ever be able to repay. It was inspiring and energizing to be a small part in the lives of truly authentic people. 


\section{TABLE OF CONTENTS}

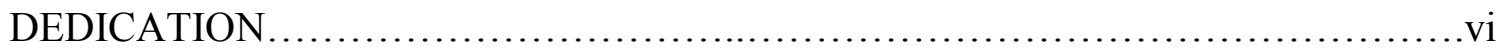

ACKNOWLEDGEMENTS .................................................... vii

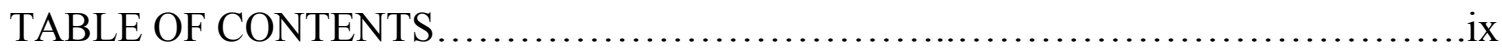

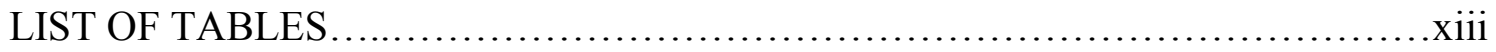

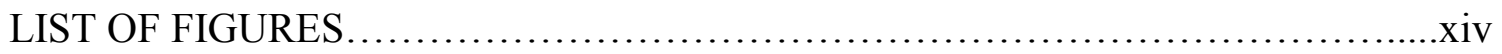

CHAPTER ONE: INTRODUCTION AND BACKGROUND OF THE STUDY.............1

Statement of the Problem......................................................6

Purpose of the Study/Research Questions...................................11

CHAPTER TWO: LITERATURE REVIEW...........................................13

Evolution of Charitable Organizations and Their Governance....................13

Client Participation in Board Decision-Making............................. 16

The Impetus for Constituent Diversity ................................16

The Rational for Client Serving as Board Members.......................17

Strategies for Engaging Clients on Boards.............................19

Alternative Strategies.................................................

An Additional Complication Associated with Having Clients as Board

Members …....................................................... 20

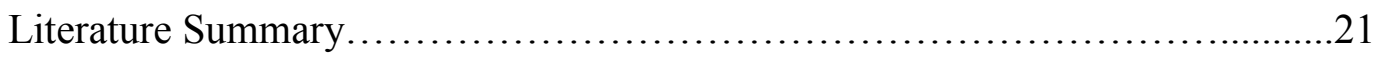

CHAPTER THREE: RESEARCH DESIGN AND METHODOLOGY ....................22

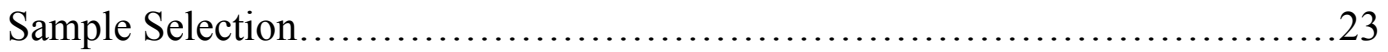

The NTEE-CC Coding System......................................23

Selecting Organizations to be Included in the Study...................25 
Research Site and Participating Organization/Participant Selection.......26

Research Site Selection..................................26

Participating Organization Selection.............................26

Data Collection Procedures..........................................28

Phase I Survey Development................................29

Phase II Survey Development.................................31

Survey Distribution.............................................33

Phase I Survey Distribution..................................33

Final Sample Adjustments.................................39

Phase II Survey Distribution................................40

Document Review.......................................41

Data Analysis..................................................43

Answering the First Research Question.......................43

Answering the Second Research Question.......................44

Answering the Third and Fourth Research Questions............46

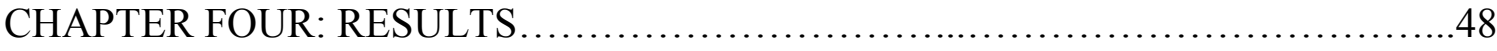

The Phase I Data........................................................ 48

Characteristics of Responding Organizations.......................48

Assessing Non-Response Bias...................................49

Answering the First Research Question.............................50

The Number of Organizations with Clients on Boards............51 
Services Provided by and the Fiscal Characteristics of

Organizations with Clients on Boards.

The Number of Organizations with Clients Involved in Other

Potential Decision-Making Activities........................54

Summary of Research Question \#1 Findings...................57

Answering the Second Research Questions............................57

Predicted Probabilities.....................................59

The Phase II Data...............................................60

Answering the Third Question.............................60

Phase II Survey Results...................................61

Review of Document Analysis Procedures...............................62

Document Review Results.................................63

ORG-B........................................64

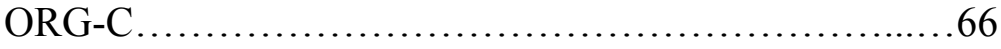

Document Review Summary............................68

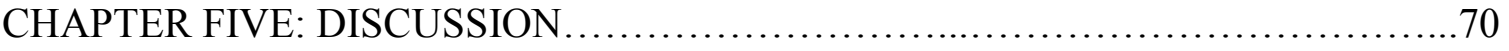

The Impetus for the Study...........................................70

Methods Employed in this Study.........................................71

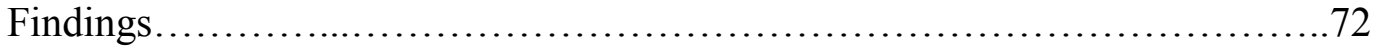

Research Questions One and Two.................................72

Research Questions Three and Four................................73 
A Comparison of this Study's Findings to the Findings of Previous

Research. 74

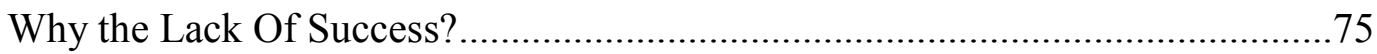

Implications....................................................... 80

Future Consideration................................................... 81

Significance, Limitations, and Delimitations........................... 82

Significance................................................ 82

Limitations...............................................83

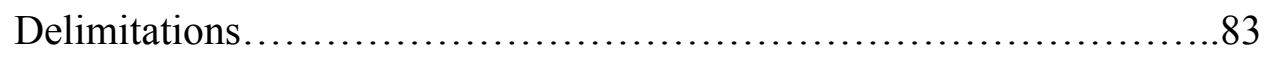

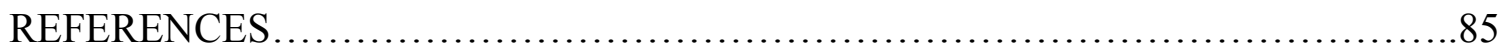

\section{APPENDICES}

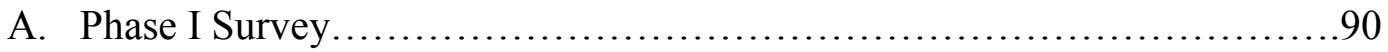

B. Phase II Survey - Email Invitation................................... 97

C. Phase II Survey................................................... 99

D. Telephone Survey Questions and Response Totals .....................110

E. Nonresponse Bias.....................................................112

F. Online Survey Responses to Demographic Questions.....................114

G. ORG-C Board Meeting Review Data.................................116

H. National Taxonomy of Exempt Entities-Core Codes (NTEE-CC)

Classification System............................................... 118 


\section{LIST OF TABLES}

Table 1. Human Services Organizations (HS) included in the survey. .................40

Table 2. Participatory actions and activities measured from board meeting Minutes/notes. ...............................................43

Table 3. Variables: type, level of measurement, and source. .....................45

Table 4. Demographics' of organizations participating in Phase I survey. .............49

Table 5. Phase I survey participating organizations by NTEE-Core Code subsector.....50

Table 6. Summary phase I survey responses - frequency of client participation by activity.

Table 7. The total number of participatory activities among responding organizations .56

Table 8. Regression output..............................................59

Table 9. Predicted probabilities.............................................60 


\section{LIST OF FIGURES}

Figure 1. Internal Revenue Service Tax Form 990 Part VII, Section A.................8

Figure 2. “Arnstein's Ladder"................................................19

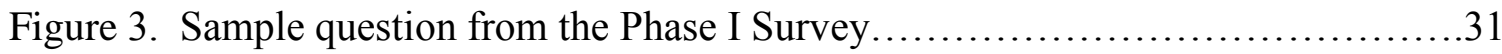

Figure 4. Sample perception questions from the Phase II survey......................33

Figure 5. Phase I Sample: percentage of Human Services organizations, survey respondents, and organizations reporting a client on the board of directors by NTEE-CC subsector .................................................53 


\section{CHAPTER 1}

\section{INTRODUCTION AND BACKGROUND TO THE STUDY}

Nonprofit/charitable organizations' origins can be traced back to the early Greeks, people for whom the concept of goodness and caring for others was first spoken of as "philanthropia" (Sulek, 2010). Sulek (2010) noted that in many cases donors in Ancient Greece did not know how their donations were used or even who they were for. Miller (2003) has argued that this legacy of a lack of oversight continued into the final quarter of the $20^{\text {th }}$ century and helps explain the fraud and financial irresponsibility that became well documented scandals at that time.

While Miller (2003) described a link between the present and the past, other scholars have emphasized changing features of the nonprofit field. Due to fluctuating economic conditions, for example, social-service-oriented nonprofit organizations have become more and more reliant on fees for services. In addition, the social services wing of the nonprofit field has had to compete more and more with for-profit organizations (Salamon, 1999). Salomon noted that there is a growing gap between what nonprofits have had to do to survive with declining resources and what the community's expectations about how nonprofit organizations should be conducting business.

Salamon (1999), in fact, posited that the gap he talked about has led

to a crisis in legitimacy for America's nonprofit sector and has manifested itself in declining public confidence, growing demands for greater accountability, challenges to tax exempt status, questioning of the sector's advocacy role, and a growing unease about a whole range of pay and pre requisite issues (1). 
At another point in the same publication, he wrote,

What this suggests is that the nonprofit sector is an inherently fragile organism, even in societies like the United States where commitment to this type of organization is an integral part of the national heritage. More than that the role and character of these organizations can no more be frozen in time than those of other types of institutions: they must evolve in response to new circumstances and adapt to new opportunities and needs. (1)

In short, philanthropic and other nonprofit organizations, as well as the statutes that regulate them, have evolved, and continue to evolve with time. Present day nonprofit organizations are required to meet very specific criteria, and their board members have a fiduciary responsibility to assure the organization adheres to the laws and regulations that govern how nonprofit organizations are formed, operated, monitored, and how they report financial information. As a result nonprofit board capacity has had increased scrutiny in the last 25 years.

Before the late 1980s, the community, in general, assumed that nonprofit organizations had the capacity to provide quality services (Bradshaw, Murry, \& Wolpin 1992). This assumption resulted in very little attention being paid to boards of directors. Today, there is a general consensus that a board of directors can have a significant impact, both positive and negative, on an organization's capacity to carry out its mission and provide quality services (Herman \& Meimovics, 1990). To be sure, as Herman and Meimovics (1990) note, it is not the board alone that makes a nonprofit organization effective; rather, it is the totality of the relationship between the board of directors and the organization's leadership that matters. However, a board's failure to meet its fiduciary 
responsibilities, with or without a positive relationship with organization's management, can have an overwhelmingly negative impact on the organization.

This last point was demonstrated by Carmen (2011) in a case study of a large nonprofit organization with a board that did not meet its fiduciary responsibilities, because it failed to limit what turned out to be excessive compensation for the organization's CEO. This lapse had a significant negative impact not only on the organization but also on the community that relied on their services. This and many other cases demonstrate that the board of directors has the ultimate responsibility to ensure that a nonprofit's actions are legitimate, i.e., in the best interest of the community (GuideStar, 2014).

In the late 20th century, following the media attention caused by corruption in forprofit corporations, many community members and civil servants wondered why the boards of these corrupt corporations did not provide better oversight of the corporation's operations and reporting. This concern led to changes in legislation that regulate corporations and their boards (Sarbanes Oxley Act, 2002). What is important to realize is that all registered 501(c)3 nonprofit organizations incorporate and must adhere to the laws and regulations of corporations (Internal Revenue Service (IRS) (2014a). Consequently, the responsibilities and power of boards, both in the for-profit and the nonprofit sectors, have increased dramatically in the past ten years.

Of course, legislation can dictate what should be and how board members should behave, but it is not clear that there are normally severe consequences for boards and board members who do not live up to their fiduciary responsibility. Part of the problem 
is that boards seldom receive public scrutiny, at least not until things begin to unravel rather dramatically. As someone who has worked in the nonprofit sector for more than 40 years, I can personally attest to the fact that boards operate not only out of public view but also out of the view of employees and clients of the organization.

The first nonprofit organization in which I worked, for over 12 years, was started by a religious businessmen's group. All I knew about the board was that there were 35 male members from the same religious denomination and that many of them did not attend meetings. It was rumored that sitting on the board of directors was part of their religious duties, as defined by their church. I, quite literally, knew nothing else about the board members who were charged with ensuring the organization served the public good, and I am skeptical that they knew anything about me or the people being served.

I worked for 30 years for a second nonprofit organization. It was not until my seventh year with the organization that I gave any thought to the board of directors. At that point the organization was in financial crisis, and, prompted by readily apparent problems, I discovered that the board of directors was comprised of four board members: the founder and executive director, the executive director's wife, and the couple that lived next door to the executive director. This organization struggled financially and when a merger opportunity presented itself in 1989 , the then executive director could not turn down the opportunity. However, the merger came with $\$ 70,000$ and the stipulation, from the organization being absorbed, that an independent board of directors would need to be created. Within one year of the establishment of an independent board of directors, the executive director resigned amid allegations of serious fiscal mismanagement and 
corruption. The organization was on the brink of bankruptcy and facing multiple regulatory citations. It has been the hard work of the board of directors and many dedicated staff that allowed the organization to continue to provide services to this day.

It is stories like this one and many more that have caused the myriad of nonprofit stakeholders: clients, employees, volunteers, funders, community members, and local, state, and federal governments to become much more diligent about monitoring the board of director's composition and their activities. There are hundreds of thousands of nonprofit organization's boards of directors in the United States and the job of monitoring all of them is a nearly impossible task given the resources dedicated to the task. The increased regulations and data collected on nonprofit boards is an effort to increase efficiency of monitoring. However, sifting through millions of pages of information is a daunting task. To further aid in increased accountability nonprofit corporations have been encouraged to form boards that will provide the necessary oversight to prevent illegal activities and ensure quality services. Diversity on the board of directors, skill sets of board members, as well as internal and external board evaluations have all contributed to the overall accountability and increased confidence in nonprofit organizations in general (McDougle, L., Deitrick, L.,Llibby, P., \& Donmoyer, R., 2008)

Diversity on a board of directors can be achieved on several levels: racial, ethnic, gender, and skills set. Clients bring a unique skillset to the board, in that, they have intimate knowledge of people served and how services are utilized. In addition to knowledge of people served and how services are utilized, Masaoka, J. (n.d.), Executive 
Director of Blue Avocado, noted in her article, Nonprofit Conflict of Interest: A 3Dimensional View,

Community organizations are based in their constituencies, and hold themselves accountable to their constituencies. Accordingly, we believe it's important to have parents on preschool boards, social service clients on the boards of providers, and artists on the boards of arts councils.

Clients bring accountability and transparency to the governing board of a nonprofit organization. Brown (2003) stated "Without clear mechanisms to educate board members about the importance of opening board process and structures to stakeholder participation, transparency is not likely." However, there is a dearth of information about the number of nonprofit organizations with clients as voting members of their governing boards, moreover information about the experiences of clients serving on boards is essentially nonexistent.

\section{Statement of the Problem}

In general, little is actually known about the composition of nonprofit corporation boards. This lack of information is interesting in that nearly all of the nonprofit associations and academic centers (Board Café, Foundation Center, Council of Nonprofit, Board Source, \& Nonprofit Resources Center) have developed and published standards with regard to the composition of a nonprofit organizations' board of directors. Only a small number of researchers, however, are collecting data on board composition. One source of information might be provided by various government entities. After all, there are very specific regulations addressing the composition of nonprofit governing boards and advisory committees for government grant recipients, and that information has to be provided in the grant application and subsequent progress reports. However, there is no 
central repository for the information and, consequently, it is nearly impossible to know much about actual board composition by examining information gathered by government agencies.

An example may be helpful here: There are specific regulations requiring that a health clinic receiving government grants must have a patient of the clinic as a voting member of the clinic's board of directors. Presumably health clinics comply with this stipulation, but there is no data base providing actual information about whether this is the case, much less about the level of engagement of clients who serve on clinic boards. Are clients who serve on health clinic boards active participants in their boards' decisionmaking process, or do they play little more than a symbolic role? We simply do not know.

Another example: Many major funders require the recipient organizations to identify their board's composition with regard to gender, race, ethnicity, age, and most government funding agencies require that recipients of services be identified. Again, there is no central repository for the information. I served on a federal and state advisory board for 10 years. The relevant regulations with regard to the composition of the board were very prescriptive. In 10 years, however, the board never met the established criteria for board composition. During my tenure on the board, I participated in several comprehensive federal audits of the board's activities. Board composition was never mentioned, when I was present, and there were no consequences for failing to meet the criteria. This in spite of the fact, that the board provided regular progress reports that clearly showed the board had failed to meet the criteria for board composition. 
Another possible source considered for gathering board composition information was Guidestar, an internet source for nonprofit corporation information. The information Guidestar provides is gleaned from tax forms on file with the Internal Revenue Services (IRS). With only a few exceptions, all registered nonprofit organizations have to file taxes, organizations with gross annual receipts exceeding $\$ 200,000$ are required to file tax form 990. Tax form 990 does have a section asking for information on the board of directors. See Figure 1.

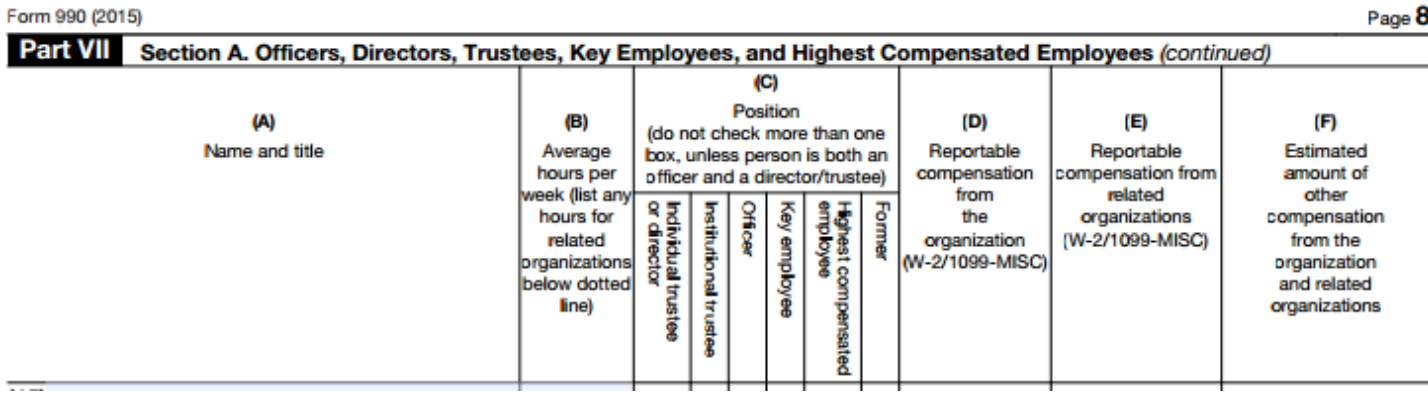

Figure 1. IRS Tax Form 990 Part VII, Section A.

This form does not require specific information regarding the relationship of the board members to the organization (Figure 1. IRS Tax Form 990).

Guidestar obtains a portion of its published information from the IRS tax form 990 (IRS General Instructions, 2014). The information required on the IRS Form 990 is basic, and organizations in general do not provide detailed information about their governance. However, organizations with Premium memberships can voluntarily provide additional information by completing a questionnaire. Guidestar publishes the information and makes it available to their Premium members. The additional information can then be used to assist volunteers, donors, and funders in making a 
decision about whether or not to support an organization. One question on the questionnaire was of particular interest to my research: "Are any clients serving on the board of directors?" In an effort to obtain this information, I contacted Guidestar. In a telephone conversation with Guidestar personnel, however, they indicated only a small number of organizations answered the question regarding clients as members of the organization's board of directors.

There are several other online resources that allow access to the 990 tax forms filed with the IRS. These tax forms can be viewed by the public. In an examination of 990 tax forms, it became obvious that most nonprofit corporations are not very diligent in responding to requests for even the most modest information about their boards.

The bottom line here should be clear: A thorough search for a data base providing nonprofit board composition information yielded no results.

A review of the literature on the composition of nonprofit boards with regard to clients as voting members yielded primarily normative discussions (e.g., boards should have clients on the board or clients on the board should be mentored) and some descriptive information (normally in the form of case studies) suggesting that diversity and inclusion should be taken into consideration with regard to board composition. Further, it should be noted that there are projects throughout the United States providing clients with the information and skills to participate on a nonprofit board (Community Tool Box, 2014).

Still, there is scarcely any empirical data regarding client participation. A comprehensive search yielded only one study (LeRoux, 2009) that provided data on the 
frequency of clients participating as board members of a nonprofit organization. LeRoux (2009), however, was not primarily focused on the extent of client participation on governing boards. Rather, data on client participation were collected as part of a larger study of Salamon's (1995) theory of "voluntary failure". Salamon theorized that organizations are more likely to be paternalistic rather that participatory if their primary source of funding is private rather than governmental. Moreover, if an organization is paternalistic, client input is neither sought nor considered when establishing policies and services.

As part of LeRoux's (2009) research, a survey was sent to nonprofit organizations in Michigan, asking organizations to identify if clients provide input to boards via one of four specific avenues: 1. Respond to surveys, 2. Participate in work groups, 3. Members of advisory boards, and 4. Members of the board of directors. LeRoux found that $49 \%$ of organizations surveyed had clients participating on governing boards. LeRoux further noted that the degree of governing board participation found in the surveys was unexpected since previous literature had indicated that most governing boards were comprised of white upper middle-class professionals. LeRoux did not offer an explanation for this finding nor did she tell us much about the actual participation of clients. Whether participation on governing boards was substantive or merely symbolic remained an unaddressed question.

To summarize, there is interest in the notion that recipients of services should be present on a nonprofit corporation's board and, even in some cases, there is a legal requirement that this occur. The rationale for doing this, of course, is to ensure that 
governing boards meet their obligation to understand the constituents they serve, an obligation of boards that virtually nobody would challenge (Brown, 2002). It is also believed that clients on the governing board will bring an increased level of accountability and transparency. It seems imperative that data is gathered regarding recipients of services and their presence or absence on nonprofit governing boards.

It is also important to understand the relationship between nonprofit organizations and government social services programs. In the late $20^{\text {th }}$ century federal, state, and local governments started privatizing their social service programs. Most government social services programs are required to have a client/recipient of services as a member of the advisory board. Government programs do not have boards of directors but each is required to have an advisory board. An example would be the Ryan White funds that the federal government gives to local communities to support the treatment of people with AIDs. Decisions about the distribution of these funds are made by advisory boards. Each advisory board is required by the federal government, which, as was just noted, funds the program, to have people with AIDS as board members (HIV/AIDS Bureau). As more and more government programs are privatized, the requirement for clients as board members has not been codified for the majority of nonprofit organizations receiving government funds. In some cases, therefore, the value of client input is being lost.

\section{Purpose of the Study/Research Questions}

This proposed modest, albeit important study was designed to provide empirical data about one aspect of the composition of nonprofit boards of directors, i.e., whether or 
not clients are voting members of the governing board. In addition to examining the frequency with which nonprofit boards have voting members who are clients, this study attempted to identify if a relationship existed between client and non-client status, on the one hand, and board member's level of participation, on the other.

This study was framed by the following four research questions:

1. How many human services nonprofit organizations in San Diego County include people who receive services on their board of directors; what are the types of services and the fiscal characteristics of organizations with clients as board members; and how many organizations involve clients in other activities that potentially involve decision-making about the organization?

2. Is there a relationship between the demographics of an organization, to include additional client participatory activities, and having participants of services as voting members of the governing board?

3. Is there a relationship in the level of engagement between client and nonclient board members on the same board?

4. What are the perceived experiences of clients and non-clients on the same board? 


\section{CHAPTER 2}

\section{LITERATURE REVIEW}

It is important to understand the evolution of nonprofit organizations and the shift in the relationship between nonprofit organizations and Federal, state, and local governments. This review will provide an understanding of what the literature says about the history of nonprofit organizations and their governing boards. The review will be organized around the following specific topics: (a) the evolution of charitable organizations from antiquity to modern nonprofits and (b) clients' participation in the governance of contemporary nonprofit organizations

\section{The Evolution of Charitable Organizations and Their Governance}

Historically, there was very little, if any, oversight of how charitable organizations conducted business. Historical accounts of philanthropy, in fact, suggest that philanthropy was not even necessarily a vehicle to cure the world's woes; rather, it often was something that people engaged in to make a statement about themselves (Robbins, 2006). In some cases charitable giving was a religious duty and a sign of piety; at other times, it was used to increase the political standing of a public figure (Robbins, 2006).

In China, philanthropy was even used by big business people to distract from the fact that businessmen were taking advantage of the general public (Bun, 2001). Robbins (2006) also has noted that, in medieval times, charity consisted of simply passing money through a slot in a nondescript door. The donor never knew where the money went or how it was used (Sulek, 2010). 
In short, the historical literature suggests that philanthropic efforts and what we now call charitable organizations often were not viewed in terms of what they could do for the general public or for those in need. More attention was paid to the giver than the receiver. It is hardly surprising, therefore, that, historically, there was very little, if any, oversight of how assets of charitable organizations were used. Miller (2003) has argued that this legacy of a lack of oversight continued into the final quarter of the $20^{\text {th }}$ century and helps explain the fraud and financial irresponsibility that became well documented scandals at that time.

Presently there are specific regulations providing clear direction for many of the functions of a nonprofit board of directors. In the late $20^{\text {th }}$ century, in fact, federal and state governments started enacting laws and regulations designed to increase accountability of nonprofit organizations. Much of the new legislation was directed at preventing fraud and financial mismanagement. The Sarbanes-Oxley Act of 2002 (Board Source, 2006), for example, was created to specifically address financial irregularities in for-profit corporations. However, there are several sections that specify compliance criteria for nonprofit corporations in such areas as employee protection, document destruction, and audit committee composition.

Perhaps the most closely watched reporting document of nonprofit corporations is now the annual tax return (IRS, 2014a). All 501(c)3 nonprofit organizations, except for religious or religiously affiliated, must file a IRS Tax Form 990. The Form 990 was revised in 2009 and now requires significantly more information than was required previously, information that often helps insure that nonprofit organizations behave 
ethically. Mitchell (2012), in fact, has taken note of "the dominance of the Form 990 as the principal nationwide, standardized accountability mechanism for nonprofit organizations in the United States" (p42).

To play out its role as a "standardized accountability mechanism" for nonprofits, Form 990 asks numerous questions about a nonprofit organization's board of directors. Arguably, the most important of these questions is whether any of the board members have a conflict of interest.

Of course, nearly all board members are likely to have some sort of conflict of interest in certain situations. Consequently, the existence of a conflict of interest does not prevent someone from participating on a nonprofit board of directors. The rational for identifying conflicts of interest on Form 990 is to encourage board members who have a conflict of interest on a particular issue (e.g., the awarding of a lucrative contract) to abstain from any actions (motions or votes) that might provide a favorable outcome for the board member (IRS 2014b). These actions (or, to be more precise, decisions to be inactive on certain issues that pose conflict-of-interest concerns) are expected to be noted in the board of directors meeting notes.

One final point, a point that can serve as a kind of transition to the next part of this literature review, a part that focuses on board composition, in general, and clients as board members, in particular: If a client serves on a nonprofit organization's board there is a potential conflict of interest in that the client could propose and advocate for policies that might solely benefit the client, himself or herself. Despite this fact, the literature indicates that there has been a substantial push to make some of a nonprofit 
organization's clients members of that organization's board. The next section discusses literature about the role and composition of governing boards of nonprofit organizations, in general, and clients serving on governing boards, in particular.

\section{Client Participation in Board Decision-Making}

The composition of the governing boards of for-profit firms and nonprofit organizations has been a topic of research since the early 1900s (Freeman 2002; Gazley, Chang, \& Bingham 2010). Miller (1999), for example, noted that a board's diversity is one of the most important issues nonprofit organizations currently face. Diversity can mean demographic diversity or constituency representation (Miller, 1999) Historically, in the demographic realm, research on board composition has addressed such issues as ethnicity, race, age, socio-economic factors, and religious diversity (Gazley, etal, 2010) Abzug (1996) concluded that there is no "one best way" (p. 110) to develop a board of directors. The board of directors should be constituted to offer the efficiency and effectiveness based on the mission and function of the nonprofit organization (Brudney \& Murry, 1998). But there has also been a push for constituency diversity, a push that has taken the form of transforming an organization's clients into voting board members of the organization.

\section{The Impetus for Constituent Diversity}

Much of the push for constituency diversity has come from government officials who increasingly rely on nonprofit organizations to deliver services the government funds (Boris, Leon, \& Nikolova, M., 2010; Miller, 1999). In 1964, for example, President Johnson suggested that recipients of services should be a part of the governance 
of organizations providing the services. President Johnson stipulated that, for specified programs that receive federal funding, direct recipients of services must participate in the boards that govern the organizations that provide the programs (United States Department of Health and Human Services the Office of Community Services, 2004). This was not an entirely new idea, however; the Public Housing Act of 1937, for example, stated that " the membership of the governing board of each public housing agency must contain not less than one eligible resident board member" (United States Housing Act of (1937 ref. \#56879).

Furthermore, constituent diversity is not just an historical phenomenon. Currently, several state and federal agencies either require primary recipients of services to participate on specific boards or they, at the very least, consider board composition when reviewing applications for funding. For example, the Federal Emergency Management Agency (FEMA) requires that two people who do not have a home —or who have recently been homeless - participate in the local governing board of the Emergency Food and Shelter Program (EFSP) (CRS Report to Congress, 2005).

\section{The Rationale for Clients Serving as Board Members}

There are reasons for having clients as board members that go well beyond the need to comply with federal or state rules and regulations. One reason is to give citizens more control over their own lives. The current literature provides many recent examples of what happens when people have no control over their own lives. In late 2014 the world witnessed one such example when the people of Ferguson rioted over the death of

a young black man. Many people living in Ferguson were interviewed. They were asked 
what they wanted to happen as a result of the riots. Although people responded differently, the overarching theme of the interviews was that people of Ferguson wanted a voice in how their community is governed.

The literature, in fact, suggests that if people have more control over their lives there may not be so many frustrated, angry, and seemingly disenfranchised people (Burger \& Cooper, 1979). The people of Ferguson were asking for justice and to have a voice in how the city hires and who they hire to patrol their streets and the policies and practices of how someone is arrested and incarcerated (Ramos \& Andersen, 2014). Those who receive services from nonprofit organizations often are asking for similar sorts of control over their lives (Shalock, 2002). Eisinger (1982) and Welch and Bledsoe (1988), for example, have noted that when people in a position to make policies have similar characteristics of the people the policies are designed to serve, the policies will be more reflective of the interests of the people being served.

Arnstein (1969) developed the concept of "A Ladder to Citizen Participation". Arnstein posited that most clients participating on government advisory boards were merely tokens. However, she stated that citizen control needs to be at the top of the ladder. Citizens should not be tokens; they need to have an opportunity to make real contributions. As shown in Figure 2, Arnstein's ladder is a way underprivileged and marginalized people can start to control their destiny. No one has a greater interest in quality services that support people in becoming more successful than the people receiving those services. 


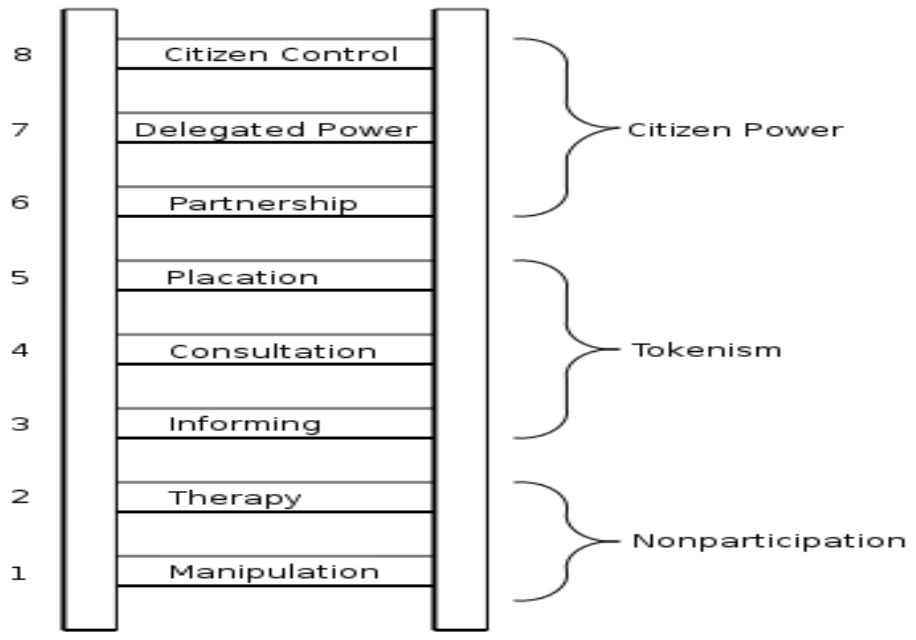

Figure 2. “Arnstein's Ladder"

\section{Strategies for Engaging Clients on Boards}

In a 1979 article with the intentionally misleading (and, in fact, satirical) title, "How to Keep Your Mandated Citizen Board out of your Hair and off your Back: A Guide for Executive Directors," Steckler and Herzog 1979 offered solid advice on how to recruit, train, and support mandated clients (or, to use their language, citizens as board members.) Steckler and Herzog suggest that there is value in citizens participating in the governance of organizations and that training and mentoring of novice board members, among other strategies, should be employed to allow organizations to benefit from citizen participation. Failure to carefully examine client or citizen participation and adapt to the needs of clients/citizen participants can pose a threat to efficient board operation by not having a clear understanding of the services offered and how those services are received and integrated into the community. 


\section{Alternative Strategies}

Of course, many boards still do not have client board members, even though it is generally accepted that responsible governing boards have an obligation to understand the constituents they serve (Brown, 2003). A technique used by many governing boards to understand their constituents are presentations by staff and constituents at board meetings. In a study of inclusive governance practices, Brown (2003) found that one nonprofit, with a 60 member Board but without primary recipient participation on the board, reported that it was able to understand the needs of its constituents because staff and service recipients did presentations at every board meeting. Brown discovered, however, that these presentations were designed as emotional appeals to elicit monetary donations from board members rather than to provide information for the board members to inform their policy decisions.

Another strategy that has been employed by governing boards in an effort to include the voice of constituents is using advisory committee (as opposed to governing board) membership (Bradshaw, 2009). Recipients of services participating as advisory board members hold the possibility of greater understanding of how services are delivered and utilized. Arnstein (1969) noted that advisory committee participation does not bring the same benefits for the recipient as actual board participation.

\section{An Additional Complication Associated with Having Clients as Board Members}

Board participation for recipients of services has been further complicated by the fact that many nonprofit boards expect their members to make monetary donations or participate in a "give or get" policy (Murray, 1996, p. 17). In these instances board 
members are required to either give a specified amount of money as a donation or obtain a specified dollar amount in the form of a donation from another source. Many recipients of services, such as individuals who are homeless or who rely on supplemental food to survive, have extremely limited resources which limits their ability to participate in such "give or get" programs.

\section{Literature Summary}

Despite nearly a century of discussion regarding primary recipients of services participating in the governance of nonprofit organizations as active board members, and despite the dedication of resources to recruit, train, and support primary recipients of services as voting board members, the literature provides meager qualitative or quantitative insight into whether there is a general practice of people receiving services participating on nonprofit governing boards. There is even less information in the literature regarding the perceptions of recipients of services with regard to organizational or personal consequences of participation as board members. Given that it is likely that there will be continued investment in recipients of services participating on governing boards, it is appropriate to explore the extent clients are participating on nonprofit governing boards and outcomes of this inclusionary strategy. 


\section{CHAPTER 3}

\section{RESEARCH DESIGN AND METHODOLOGY}

This exploratory sequential mixed methods study was constructed to examine the frequency and degree of client participation as voting members of nonprofit human services organizations' governing boards in San Diego County, as well as their involvement in other organizational activities that are likely to entail some sort of organizational decision-making. The first phase was designed to determine the frequency and kinds of client participation (e.g., serving on advisory committees and work groups, participating in surveys, holding membership in the organization, and, especially, serving as a voting member of a nonprofit organization's board of directors) as well as to examine the organizational characteristics that are associated with clients serving as board members of the organization they receive services from. The second phase was designed to gain a better understanding of the degree of client participation as voting members of governing boards of directors by focusing on whether client board members did the sorts of things that other board members do during board meetings.

This chapter focuses on the methods used in conducting the study and the assumptions that influenced the selection of the different methods employed. The flow and structure of the two phases of the study will also be identified. 


\section{Sample Selection}

\section{The NTEE-CC Coding System}

The sample was selected using the National Taxonomy of Exempt Entities Core Codes (NTEE-CC). All registered nonprofit corporations are categorized using the NTEE-CC. NTEE- Core Codes were developed in the early 1980s and widely adopted in the early 1990s by both the Internal Revenue Service (IRS) and the National Center for Charitable Statistics (NCCS) (NCCS, 2016). In an article published in the New York Times in 1986, the developer of the NTEE- Core Codes was quoted as part of a discussion of how the codes would be beneficial to researchers. The author of the article wrote,

Today's researchers in the field will be assisted by a new computerized system for classifying nonprofit groups which, for the first time, will identify the beneficiaries as well as the purposes of each nonprofit organization. The system was designed by Russy D. Sumariwalla, senior vice president of United Way, for the National Center for Charitable Statistics, now part of the Independent Sector. "When the system is fully functioning, we will have a clearer picture, for example, of which organizations are helping targeted groups such as minorities, the aged and disabled, women and children, refugees or whatever," he said. (Teltsch, K. (1986))

The NTEE-Core Codes are not assigned arbitrarily but rather are based on information gathered from the organization's filing for 501(C)3 status and various other reports filed with the IRS. The mission and vision of an organization are considered when associating a specific organization with a specific code.

Organizations are classified by an alpha-numeric system. The code classifies organizations with major codes using A through $\mathrm{Z}$. The major code provides a broad description of the services offered. For example organizations in the code A are 
primarily offering services in the areas of arts, culture, and humanities, while organizations with a major code of "U" would be primarily addressing issues related to science and technology.

Organizations in the 26 alpha categories are further delineated by a numeric system of 681 decile codes, 01 through 99 for each major code. These decile codes provide greater specificity about the services provided by organizations in each alpha category. For example in the major category A (arts, culture, and humanities), organizations with the alpha/decile code A30 concentrate on media and communications. Similarly, in the human services area (i.e., category P), P30 organizations primarily serve children and youth.

Both the Internal Revenue Service (IRS) and the National Center for Charitable Statistics (NCCS) use the NTEE-Core Codes. They use the codes to designate the type and nature of services provided by registered 501(c)3 (nonprofit) organizations.

In 2013, there were a total of 945,393 501(c)3 nonprofit organizations operating in the United States with 28,852 nonprofit organizations, including private foundations, operating in California. Of the 28,852 nonprofit organizations in all categories in California in 2013, 9,700 operated in San Diego (Deitrick et al., 2013).

When the NTEE coding process was employed in 2013, the "Human Services" category was third among the top five largest categories, by frequency, with 83,538 organizations in the United States. (The largest category was "Religious, Spiritual Development" with 92,996 organizations in the United States, followed by the second 
largest category "Education" with 90,854 organizations in the United States (Guidestar, 2013)).

\section{Selecting Organizations to be Included in the Study}

This study examined nonprofit organizations classified by the IRS and NCCS as NTEE-Core Code P, Human Services organizations. As noted above, within the Major Code $\mathrm{P}$ there are decile code classifications 01 through 99. (See Appendix H for the full list of NTEE-Core Codes and subsectors.) Human Services Organizations were selected because they represent a large number of nonprofit organizations, and it seemed likely that there would be clients involved in the decision-making process of the organizations in this category. It seemed reasonable to assume that organizations that supply services would want representatives from the groups served on their boards (and involved in other venues that impact organizational decisions) because, presumably, such organizations would want to tap the perspectives and experiences of those who receive services. Organizations in other categories such as arts organizations are more likely to place donors on their boards, and the two largest categories, religion and education, have such broad constituencies that it is almost impossible to not have clients on boards in these areas.

In summary, nonprofit Human Services Organizations in NTEE-Core Code P were selected because there is a higher number of organizations and, consequently, the possibility of a larger sample size. Additionally, unlike some organizations in Major Codes, Human Services Organizations seemed to hold a greater likelihood of a client 
participating on boards of directors for the organization for the sole purpose of gaining the client's perspective on service utilization and an understanding of who is being served by the organization.

\section{Research Site and Participating Organization/Participant Selection}

Research site selection. The research location was San Diego County, California. The selection of San Diego County represents a combination of convenience and criterion sampling strategies. This is where I live, but the area is also home to a robust nonprofit community. In 2010, for example, the National Center for Charitable Statistic Urban Institute data base listed 13,001 nonprofit organizations in San Diego County. At that time, the county had the second highest number of nonprofit organizations of any municipality in California; only Los Angeles had more nonprofits listed (NCCS, 2010). Furthermore, the profile of nonprofit organizations in San Diego County closely approximates the State and Federal profiles of nonprofit organizations (Deitrick et al., 2013).

Participating organization selection. The process to select participating organizations began by requesting the most recent available list of human services organizations as defined by their NTEE-Core Code in San Diego County from the NCCS. I received information from the IRS Business Master File records for San Diego County Public Charities coded NTEE $=$ P (711 total) from Jon Durnford, a researcher associated with NCCS. The most recent complete set of data available at the start of the study was for the year 2013 . 
Jon wrote he had gleaned the list from the NCCS data base by using the "strictest" definition of Human Services Organizations. Many organizations providing human services can also be found in the following NTEE-Core Codes: I, J, K, L, M, N, and O, but these organizations were not included in this study. Additionally, many organizations provide services in multiple categories. In short, using the "strictest" definition of organizations designated in the NTEE-Core Code, Human Services, subsector P, were included in this research in an effort to avoid confusion regarding the composition of the sample and offer the best hope of replication.

The 711 organizations identified by using the "strictest" definition the Human Services subsector represented $63.5 \%$ of all human services organizations in San Diego County.

To determine my sample for the first phase of my research, one additional filtering mechanism was used: organizational income. Only organizations that showed income on their IRS 990 tax form for 2013 became part of the sample data base. After the income filter was applied, the sample consisted of 350 organizations.

The income filter was applied as a proxy for organizational capacity, especially the capacity to respond to requests for information about the organization. My experience doing prior research suggested that smaller nonprofit organizations that do not reported income have, by definition, fewer resources and, consequently, are less likely to have the ability to respond to or even access online surveys. While working in the Caster Center for Nonprofit Research at the University of San Diego, my colleagues and I spent untold hours trying to identify nonprofit organizations and obtain contact information, 
with little success. When we were successful in contacting smaller organizations with little or no income, organizational representatives frequently indicated their organizations were run solely by volunteers. These people often indicated they did not have the time or the knowledge to respond to our inquiries.

The 350 organizations that remained after the income filter was applied became the initial sample for Phase I of the study. Later, the number was slightly reduced because of such things as (a) an organization was no longer in business, (b) an organization had merged with another organization, (c) an organization had an office in San Diego County but did not provide services in San Diego County (in most of these cases, services were provided in Mexico), or information about the organization could not be found. After organizations were taken off the list for these sorts of reasons, the sample size was reduced to 275 .

The Phase II sample was generated from the Phase 1 data. All organizations that Phase I data indicated had at least one client as a voting member of the organization's board of directors were invited to become part of the Phase II sample. The plan was to have those organizations that agreed to participate in the study make up the Phase II sample. As will be discussed later, this plan turned out to be quite problematic.

\section{Data Collection Procedures}

This section begins with a discussion of the search for and the development of a survey to be sent to the sample organizations. A rigorous search of available literature and the internet for a possible survey instruments that would provide answers to the 
research questions was conducted. No appropriate instruments were found. Consequently, I ended up constructing survey instruments for both phases of the study.

Phase I survey development. The Phase I survey was created using the Qualtrics platform. This survey was designed to determine the frequency of client participation in a variety of activities that have the potential to inform the decisionmaking processes of nonprofit human services organizations, including participation on an organization's board of directors. The Phase I survey consisted of 23 multiple choice and short answer questions.

The first priority of the survey was to verify that the organization met the criteria for inclusion in the study. This verification was accomplished by two survey questions. Participants were asked to identify either the organization's legal name or their Employer Identification Number (EIN). This information permitted me to verify that the organization responding was a member of my sample.

This verification process was required because the survey was to be sent to individuals as opposed to organizations, and it was possible that the individual could have a relationship with several organizations. Moreover, one or more of the organizations the individual was associated with may not be part of the research sample.

An additional question, a question designed to determine if services were being provided in San Diego County, asked the participant to select from three choices: "Does your organization provide services: in San Diego County, in San Diego County and other areas, or not in San Diego County." 
The survey also asked for basic demographic information about the organization and the executive director. Previous research (LeRoux, 2009) suggested that both the demographics of the organization and the background and characteristics of the executive director might be predictive of the level of client participation in the decision-making processes of nonprofit organizations. LeRoux found also a relationship between the sources of income the level of participation by clients. LeRoux concluded that government funding was likely to increase client participation. Sources of income are not identified in the NCCS data that information would have had to be gathered from the Phase I survey. In an effort to streamline the Phase I survey, I decided to not include a question regarding sources of income. However, online survey participants indicating there was a client on their board of directors were asked if their organization was required to have a client on the board and then select from the following options why there was a requirement: Government requirement, funder requirement, or organizational charter.

The remaining questions were designed to determine the frequency and nature of client participation. Figure 3 contains a sample question from this part of the survey. 
Do people who receive services from your organization participate in the following decision-making activities, in support of your organization?

(Please check all that apply.)

- $\square$ Membership

- $\square$ Advisory committees

- $\Gamma$ Voting members of the organization's board of directors

- $\square$ Working groups

- $\square$ Participating in surveys

- $\quad$ None of the above

- $\square$ Other

Figure 3. Sample question from the Phase I Survey

Organizations indicating the presence of a client on the board of directors were then asked additional questions about the total number of board members, the number of clients who serve as board members, if the organization is required to have a client on the board and, if so, why, and the frequency of board meetings. The last question inquired about whether the organization would consent to participate in the second phase of the study. (The entire first phase survey can be found in Appendix A.)

Phase II survey development. The Phase II survey also was designed using the Qualtrics platform. This particular survey was designed to collect data from individuals anonymously. The only potential identifying information requested was whether or not the individual is currently receiving services from the organization.

The survey was tailored to each organization that agreed to participate. For example, all questions related to the organization identified the organization by name.

The first two questions were designed to confirm that the individual responding to the survey was a voting member of the target organization and to determine whether the 
individual responding was a client currently receiving services from the organization. Questions following confirmation of the individual's relationship to the organization were in two blocks.

The first block of questions was designed to examine the degree to which the person participated in the organization and, more specifically, whether they were on the board of directors. Examples of questions in this category include questions about how often the person attend board meetings, had they held an officer position, did they volunteer for other activities sponsored by the organization, and had they chaired any committees.

The second block of questions was designed to examine individual board members' perceptions of their experiences as a board member. This block asked about such things as whether the respondent felt welcome at board meetings and whether they thought they were bringing value to the board and the organization, in general. The final two questions asked whether they would serve on the board of directors again after their current term expired and whether there was anything about the board or their service on the board they would like to see changed.

Questions on the Phase II survey were either multiple choice or used a sliding scale for responses. A three or four point Likert Scale with an available comment box was used to ask questions about board members' perceptions. Examples of the Likert Scale perception questions are in Figure 4. See Appendix C for the complete Phase II survey instrument. 
Do you feel your service on the board has been valuable to you? (Please feel free to add a comment.)

- Yes

- $\mathrm{O}$ No

- Maybe

Do you feel you are making a valuable contribution to the board? (Please feel free to add a comment.)

- All the time

- Most of the time

- Sometimes

- I don't know

Figure 4. Sample perception questions from the Phase II survey

\section{Survey Distribution}

Phase I survey distribution. After the Phase I survey was developed, I consulted the list of the 350 nonprofit organizations that remained in the sample, after the income criterion mentioned earlier was applied, and attempted to identify contact information for the executive director of each organization on the list. The NCCS data base initially was used. This data based provided the Employer Identification Number (EIN), the legal name of organization, its address, and, in some cases, a telephone number for the organization. 
The NCCS data does not always list the executive director. In fact, I discovered that, frequently, the NCCS contact information was outdated and incomplete. NCCS obtains information from IRS Tax Form 990. Most often the contact person listed in the NCCS data turned out to be the person who completed the organization's IRS Form 990 tax return. Often, this person was a tax preparer who did not have an ongoing relationship with the organization. Moreover, the data obtained from NCCS was from 2013, and it was not uncommon for the person identified in NCCS data to no longer be associated with the organization.

Because of the two limitations with NCCS data, an exhaustive search was conducted to obtain contact information for the executive director or board president for the 350 Human Services Organizations with income in San Diego County. Several resources were employed: NCCS, of course, Guidestar, California State Department of Justice, and the internet. Guidestar was generally the most helpful.

Guidestar provides basic information for all nonprofit organizations registered with the IRS, and they also obtain most but not all their information from the IRS tax form 990. Guidestar data were important in making an initial determination if an organization identified in the NCCS data was currently registered with the IRS as a 501(c) 3 and if the legal name of the organization was the same as the name listed in the NCCS data. Guidestar member organizations can voluntarily provide additional information to be posted on Guidestar's website. Enhanced Guidestar data may contain complete contact information: website, telephone number, and address, as well as 
information on people associated with the governance of the organization, e.g., the organization's executive director or board members.

The search was broadened, to include websites, corporate review sites, and other social media resources. Through painstaking effort, the email addresses for 181 of the 350 organizations with income in 2013 were obtained. In addition to obtaining the executive director's or board president's email addresses, data about the physical address and telephone numbers for the sample organizations were also collected.

Unfortunately, no contact information about an organization's website, email address, telephone number, or physical address could be found for 35 of the 350 organizations in the sample database. Many of the smaller organizations that seem to be operated solely by volunteers did not appear to have websites, offices, or dedicated telephone numbers. Lacking any contact information, I eventually dropped them from the study sample.

At the end of the search process described above, contact information on a total of 181 organizations had been generated. Email invitations were sent out in three batches, starting on December 10, 2015 with the last batch sent out February 2, 2016. As contact information was gathered, rather than waiting on contact information for all 350 organizations in the sample, the survey was sent out when a reasonable number of organizations' contact information were obtained. Three batches ranging in size from 26 to 98 were sent out. Batches were sent out approximately three weeks apart. 
Included as part of the introductory email inviting organizations to participate in the Phase I survey was a brief summary of the study and the survey link. Over the next two months, mid-December 2015 to mid-February, 2016, two follow-up emails with a link to the survey included were sent as reminders to those who had not participated in the survey. Emails also were sent to those who had already participated, to thank them for their participation.

By March 10, 2016, only 30 survey responses had been received. In an effort to increase the number of responses, before the third and fourth round of reminders were sent out, the survey's appearance was changed. Page breaks were removed and the word "Optional" was added to each of the demographic questions regarding the executive director. These questions did not have to be answered to move on, but, to be clearer about this point, the word "Optional" was added. These changes were made with the thought in mind that some participants might view questions regarding race and gender as too intrusive. The hope was that if these questions were clearly labeled as optional, there would be an increase in the response rate. A copy of the survey with modifications identified is included in Appendix A.

I also made an effort to increase the respondent pool by attempting to contact, by telephone, the remaining 275 (350 organization minus the 35 without contact information and minus the final count of 40 organizations that had already responded to the survey). This pool of organizations to be contacted by telephone included organizations without email addresses and all organizations that had not responded to the survey invitation. 
The organizations designated for telephone contact were placed in random order using the organizations' EIN and an online randomizer. The randomized list was used to make telephone contact with the executive director or anyone within the organization who had knowledge of how clients were involved in the decision-making processes of the organization.

Initially, interviewees were asked questions as they appeared in the internet survey. However, after the first few telephone interviews, it seemed as though there was significant hesitation answering demographic questions about the executive director. In addition, I had a clear sense that respondents were becoming impatient because the interview was too long. Again I made a decision that I hoped would yield additional responses: I opted to focus exclusively on the survey questions about participation of clients in the decision-making processes of the organization.

When telephone contact was made, I provided a brief description of why I was calling and asked to speak to the executive director or anyone having information regarding clients' participation in the decision-making process of the organization. This initial explanation included a list of the possible activities a client might participate in. (See Figure 3.)

If the person I initially made contact with agreed to answer the survey questions, I started the survey. If, on the other hand, I was directed to someone that could answer my questions, I again provided a brief summary of my research and again described the activities that might influence the decision-making process of the organization. This was 
followed by asking them if they would agree to answer questions about clients participating in activities that have the potential to inform the decision-making process of the organization.

I did have several people ask if I could send them something by email rather than answering questions on the phone. However, no one responded to the emails I sent.

After the individual on the telephone agreed to participate and I established that the organization provided services in San Diego County, the next telephone survey questions related to client participation activities, operationally defined as participatory activities.

The telephone survey questions were;

1. Do you agree to participate in the survey?

2. Does the organization provide services in San Diego County?

3. Do clients have membership in the organization?

4. Do your clients participate in organizational advisory committees?

5. Is there a client on the board of directors?

6. Do clients participate in work groups?

7. Do clients receive surveys from the organization?

If the organization representative indicated that there were clients on the board, then additional questions were asked about the total number of board members, total 
number of clients serving as board members, and the frequency of board meetings. Finally, following a brief description of the second phase of the study, I asked if their organization would be willing to participate in the study's second phase. If the individual agreed to have the organization participate in the study's second phase, I requested contact information and in return shared mine. I told them I would be sending an email with a link to second phase survey and suggested language they could share with the board members.

I left 26 messages ( 2 called back), 3 had wrong numbers, and encountered 16 recordings (I did not leave a message), 4 could only be contacted via their website, and 3 organizations declined to participate, one saying it was none of my business. I attempted to make telephone contact with 150 of the remaining 285 organizations. I ended calling when I had obtained a total of 61 responses, bringing the response rate to $20 \%$.

In summary, when I was able to successfully make telephone contact with someone, after providing a brief description of the study and asking if the person would be willing to be interviewed, I asked only questions related to client participation in the various activities that potentially contribute to the decision-making processes of the organization. Only after the interviewee reported that there was a client on the board, did I probe for board information.

Final Sample Adjustments. When I had completed collecting survey responses, the original sample of Human Services organizations with income in San Diego County was adjusted for organizations no longer in operation (16), duplicated organizations or 
declined to participate (9), organizations without services in San Diego County (15), and organizations without contact information (35). With these adjustments the sample size was reduced to a total of 275, from the original 350 Human Services organizations with income in San Diego County. With the adjusted sample size, the actual response rate was $22 \%$. The online survey was completed by 25 organizations and the remaining survey responses, 36, were completed in the telephone interview. See Table 1 for sample adjustments.

Table 1.

Human Services (HS) organizations included in the survey.

\begin{tabular}{ll}
\hline & \begin{tabular}{l} 
Cumulative total \\
\cline { 2 - 2 } HS organizations in San Diego
\end{tabular} \\
$\begin{array}{ll}711 \\
\text { Less HS organizations in San Diego County without income (361) }\end{array}$ & 350 \\
$\begin{array}{l}\text { Less HS organizations no longer providing services or do not } \\
\text { provide services in San Diego County 2015 (31) }\end{array}$ & 319 \\
$\begin{array}{l}\text { Less HS organizations duplicated or declined to participate (9) } \\
\text { Less HS without contact information (35) }\end{array}$ & $\begin{array}{l}310 \\
275 \text { Final Sample } \\
\text { size }\end{array}$ \\
\hline
\end{tabular}

Phase II survey distribution. The Phase II survey was designed to be distributed to all of the board members of an organization that agreed to participate in Phase II of the study by a representative of the agency. This method of distribution was designed to assure anonymity for the survey respondents. The only potential identifying information asked in the survey was if the person was currently receiving services from the organization. See Appendix C for a copy of the survey. 
The plan was to send an email to the representative of all organizations agreeing to participate in Phase II. The email expressed appreciation for their willingness to participate along with a brief explanation of the purpose of the survey. The email included sample language that could be used when distributing the survey to the organization's board members and, finally, a link with instructions on how to follow the link. See Appendix B for a copy of the email.

As it turned out, there were major problems with this design. These problems are discussed in the results chapter that follows.

Document review. Thirty-two hours of board meeting notes from three organizations were reviewed. Only two of the organizations that participated in Phase I of the study agreed to participate in Phase II of the study. One of these organizations participated in the online survey and the other participated in the telephone survey. The board meeting notes for the organizations that agreed, at the end of the telephone survey to participate, did not provide any information about which board member might be a client and there was nothing in the minutes that signaled this information. Consequently, these minutes could not be analyzed to answer Research Question 3.

Board meeting notes for the second organization did identify a client by designating them as a "Client Representative." These minutes were somewhat problematic, however, because clients represented other organizations and representatives from these other organizations frequently changed. I did make an effort to analyze these minutes despite the problems they presented. 
I was able to review the board meeting notes of one other organization with clients participating on the board as members. This organization did respond to the Phase I survey and did report having two clients on their board. However, this organization declined to participate in the Phase II survey. When I contacted the organization to ask if I could obtain their board meeting minutes for the most recent 12 months, I was told the minutes were online. The online minutes from March 2015 to March 2016 were reviewed.

Thus, the document review was conducted to estimate, in two organizations, the extent of participation of all board members on boards with clients as voting member. For purposes of the document review, board member participation was operationally defined as a combination of: board meeting attendance, the total number of times a board member made a motion, seconded a motion, or asked a question, participated on a committee; and served as an officer or committee chair. Table 2 identifies the actions and activities measured for each of the board members. All actions or activities were weighted equally. 
Table 2.

Participatory Actions and Activities measured from board meeting notes

Activity in previous 12 months

Number of meetings attended

Number of times asking questions

Number of seconds to motions

Number of motions made

Participates on a committee

Chaired an Ad Hoc committee

Chaired a standing committee

Serves as a board officer

Serves as board president

\section{Data Analysis}

Answering the first research question. The organizational survey data were used to answer the first two research questions. The first question (How many human services nonprofit organizations in San Diego County include people who receive services on their board of directors; what are the types of services and the fiscal characteristics of organizations with clients as board members; and how many organizations involve clients in other activities that potentially involve decision-making about the organization?) was answered through descriptive statistics. Specifically, the descriptive part of the analysis of the Phase I survey data reported the number and 
percentage of organizations that had and the percentage of organizations that did not have clients as board members. A description of specific demographic information of organizations with clients on their board and those that do not have clients as board members also was part of this analysis.

Answering the second research question. Is there a relationship between the demographics of an organization, to include additional client participatory activities, and having participants of services as voting members of the governing board? Inferential statistics were employed to answer the second research question; specifically, binary logistical regression was employed to explore relationships between (a) having clients as board members (the dependent variable) and (b) demographic variables traditionally associated with human services organizations and additional operationally defined client participatory activities. In other words, binary logistical regression analysis was used to estimate the extent to which the presence of clients as voting members of the board can be explained by both specific demographic characteristics of an organization and the independent variables and client involvement in other activities that presumably either involve or inform organizational decision-making. The literature (e.g., LeRoux, 2009) suggests that the demographic variables employed and the additional participatory activities variables may impact the presence or absence of client participation on a governing board. Table 3 identifies each variable by type, level of measurement, and source.

A dummy variable was used for the presence (1) or absence (0) of clients on the governing board. Organizational demographic data included: services provided (using 
the expanded National Taxonomy of Exempt Entities-Core Codes (NTEE-CC), age of the organization (using the Internal Revenue Service (IRS) Rule date), and total yearly income. Additional client participatory activities coded using a dummy variable (one for participation and zero for no participation) were: organizational membership, participating on advisory boards, participating in organizational work groups, and clients invited to participate in surveys.

Table 3

Variables: Type, level of measurement, and source

\begin{tabular}{|c|c|c|c|c|}
\hline \multirow{3}{*}{1} & Variable & Type & Level of Measurement & Source \\
\hline & $\overline{\text { Clients on the Board }}$ & $\overline{\text { Dependent }}$ & $\overline{\text { Categorical (Binomial) }}$ & $\overline{\text { Phase I }}$ \\
\hline & & & $\begin{array}{l}\text { Dummy variable defined as zero for } \\
\text { the absence of clients and one for the } \\
\text { presence of clients. }\end{array}$ & Survey \\
\hline \multirow[t]{2}{*}{2} & Clients with & Independent & Categorical (Binomial) & Phase I \\
\hline & Membership & & $\begin{array}{l}\text { Dummy variable defined as zero for } \\
\text { client nonparticipation and one for } \\
\text { the client participation. }\end{array}$ & Survey \\
\hline \multirow[t]{2}{*}{3} & Clients on Advisory & Independent & Categorical (Binomial) & Phase I \\
\hline & Boards & & $\begin{array}{l}\text { Dummy variable defined as zero for } \\
\text { client nonparticipation and one for } \\
\text { the client participation. }\end{array}$ & $\begin{array}{l}\text { Survey } \\
\text { NCCS }\end{array}$ \\
\hline \multirow[t]{2}{*}{4} & Clients in Work & Independent & Categorical (Binomial) & Phase I \\
\hline & Groups Income & & $\begin{array}{l}\text { Dummy variable defined as zero for } \\
\text { client nonparticipation and one for } \\
\text { the client participation. }\end{array}$ & Survey \\
\hline \multirow[t]{2}{*}{5} & Clients invited to & Independent & Categorical (Binomial) & Phase I \\
\hline & participate & & $\begin{array}{l}\text { Dummy variable defined as zero for } \\
\text { client nonparticipation and one for } \\
\text { the client participation. }\end{array}$ & Survey \\
\hline 6 & Services Provided & Indepe & NTEE-CC subsector- finite & NCCS \\
\hline 7 & IRS Rule Date & Independent & Continuous & NCCS \\
\hline 8 & 2013 Income & Independent & Continuous & NCCS \\
\hline
\end{tabular}


Answering the third and fourth research questions. The research design anticipated answering the third research question (Is there a relationship in the level of engagement between client and non-client board members on the same board?) and the fourth (What are the perceived experiences of clients and non-clients?) by analyzing data generated by a second survey, as well as by analyzing meeting minutes over the course of a year. As it turned out, only two organizations volunteered to distribute the survey to their board members and board members from only one organization actually filled out the second survey. Even these data could not be used, however, because the client on the board did not identify herself or himself. One consequence of this situation is that the fourth research question - i.e., the question that asked about the perceptions of client and non-client board members on boards that have clients as board members - could not be answered.

I did attempt, however, to answer the third question by reviewing meeting minutes from two organizations whose minutes were available on line for anyone to see (and analyze). (A third organization provided its minutes but these could not be analyzed because the client member of the board could not be identified.)

Meeting minutes were used to operationalize the level of participation for board members of a board with a client as a board member. Board member participatory activities were coded using the categories in Table 3 above and descriptive statistics were employed to characterize the relationship between client and non-client participation in board actions and activities. 
In total, 32 hours of board meeting notes were reviewed from two organizations with an identified client on the board. Descriptive data on participatory activities were collected and reported from the board meeting notes. 


\section{CHAPTER 4}

\section{RESULTS}

\section{The Phase I Data}

Phase I data were collected from nonprofit organizations responding to the Phase I survey. Of the 275 organizations in the sample, 61 participated in either the online survey or the telephone survey. Twenty five organizations completed the online survey and 36 organizations participated in the modified survey by telephone. The total response rate was $22 \%$.

\section{Characteristics of responding organizations}

Information about the characteristics of responding organizations is summarized in Tables 4 and 5. In addition to the organizational characteristics data summarized in Tables 4 and 5, I also collected, information in the online survey about Executive Director characteristics' and each organization's expenses. Because the telephone survey needed to be substantially abbreviated to insure that respondents did not become impatient and end the telephone survey before important items were covered, I eliminated the questions about executive director characteristics and expenses from the telephone survey. Consequently, I will not report this information here. Those interested in this information generated by the online survey only can turn to Appendix F and those interested in the telephone interview response can turn to Appendix G. In this chapter, only combined results for items that were included in both versions of the survey will be presented. 
Table 4

Demographics' of organizations participating in Phase I survey.

\begin{tabular}{|c|c|c|c|}
\hline Demographic & Range & Mean & $\underline{\text { Medium }}$ \\
\hline Rule Date & $1946-2014$ & 1994 & 1997 \\
\hline Assets & $\begin{array}{l}\$ 0- \\
\$ 37,589,452\end{array}$ & $\$ 2,735,011$ & $\$ 516,066$ \\
\hline Income & $\begin{array}{l}\$ 2,061- \\
\$ 33,232,963\end{array}$ & $\$ 3,020,692$ & $\$ 518,107$ \\
\hline Revenue & $\begin{array}{l}\$ 2,061- \\
\$ 33,152,546\end{array}$ & $\$ 2,876,130$ & $\$ 487,683$ \\
\hline
\end{tabular}

\section{Assessing Non-response Bias}

The survey data gathered in the first phase were tested for non-response bias.

Using the Chi-Square distribution, the observed frequencies for each of the ten National Taxonomy of Exempt Entities-Core Codes (NTEE-CC) subsectors in the sample were compared with the expected frequencies for these subcategories based on their respective shares in the population. The resulting test statistic revealed that there was no evidence of non-response bias, since the value of the test statistic did not exceed the critical value from the Chi-Square distribution; in other words, the null hypothesis that the observed and expected frequencies were similar could not be statistically rejected at the $p=.01$ level. See Appendix E for nonresponse data.

Although the formal test for nonresponse bias suggested no non-response bias, it is still possible that self-selection bias is reflected in the findings. There is a tremendous 
stakeholder pressure on nonprofit organizations to adhere to all the government regulations and community expectations. Compounding this increased scrutiny is the fact that nonprofit organizations tend to have very limited resources. Organizations, both large and small, might have been concerned that their answers would reveal some organizational deficiencies or weaknesses. That concern might have been a deterrent to participation in the survey. Furthermore, even if there was no requirement that an organization have a client on its governing board, it is possible that some organizations may not have wanted to expose the fact that they did not have client board members in a study focused on this phenomenon.

Table 5

Phase I survey participating organizations by NTEE-Core Code subsector.

\begin{tabular}{lrrrrrrrrrr}
\hline \multirow{2}{*}{ Subsector } & P0-9 & P10- & P20- & P30- & P40- & P50- & P60- & P70- & P80- & P90- \\
& & 19 & 29 & 39 & 49 & 59 & 69 & 79 & 89 & 99 \\
\hline Frequency & 2 & 1 & 6 & 4 & 10 & 6 & 4 & 9 & 17 & 2 \\
\hline
\end{tabular}

\section{Answering the first research question}

The first research question had three parts: (a) How many human services nonprofit organizations in San Diego County include people who receive services on their board of directors; what are the types of services and the fiscal characteristics of organizations with clients as board members; and how many organizations involve clients in other activities that potentially involve decision-making about the organization; (b) what are the types of services and the fiscal characteristics of organizations with clients as board 
members; and (c) how many organizations involve clients in other activities that potentially involve decision-making about the organization? Phase I survey results, consequently, were analyzed to determine (a) the number of Human Services Organizations reporting clients as voting members on their board of directors, (b) the general services provided (defined by their NTEE-Core Codes) and the fiscal characteristics of organizations with clients participating as board members, and (c) the number of organizations reporting clients participating in other types of potential decision-making activities. These results are discussed in this section.

The number of organizations with clients on boards. Of the 61 responses to both the online and telephone versions of the survey, fourteen organizations, or $23 \%$ of the responding organizations, reported having clients as voting members on their organizations' boards of directors. One organization with a client on the board reported that there were two clients on the board, and the remaining thirteen organizations reported they had one client on the board.

Six organizations with clients on the board of directors also had clients who held membership in the organization. Seven of the fourteen organizations with clients as board members also reported that clients served on advisory committees, and six reported that clients participated in work groups. Ten of the fourteen organizations with clients on their boards reported that clients also participated in surveys sent out by the agency. The Phase I survey did not ask if the clients participated in surveys that were sent solely to the board of directors or general surveys sent out to clients and board members. 
Some organizations that did not have clients on their boards also, at times, involved clients in other activities that potentially entailed decision-making about the organization. This information will be presented in the discussion of the third part of Research Question 1 below.

The services provided by and the fiscal characteristics of organizations with clients on boards. Ten of the 14 organizations that reported having clients as board members were in the P 80 to 89 NTEE-CC subsector. Organizations in this category promote independence for specific populations, e.g., the disabled, persons with HIV/AIDS. The remaining four organizations were each in a different category that signaled a different kind of services provided. The four subsectors outside the P80-89 subsector were:

1. P20 - Human Services, generally large affiliated organizations, Red Cross, Salvation Army, etc. (These are NTEE-CC examples of this subsector and were not necessarily participants in the survey.)

2. P52 - Personal Social Services, financial services, transportation assistance, etc.

3. P70 - Residential and Adult Day Care, generally for specific populations; mental health, disabled, etc.

4. P99 - this is a miscellaneous category, organizations in category have provided statements of activity that does not neatly fit into any specific NTEE-CC 
See Figure 5 for a graph of the NTEE-CC subcategory distribution for organizations reporting that there was a client on the board of directors.

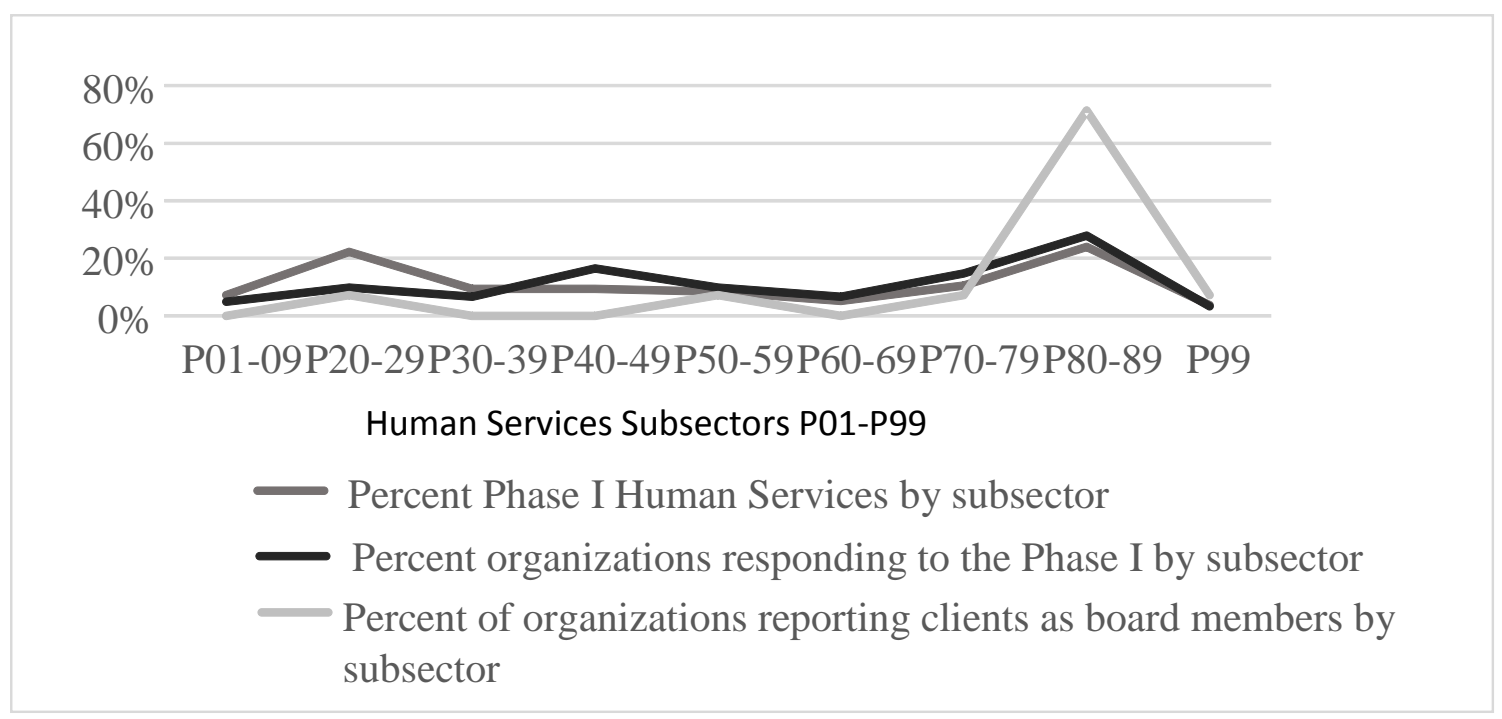

Figure 5. Phase I Sample: percentage of Human Services organizations, survey respondents, and organizations reporting a client on the board of directors by NTEE-CC subsector

The average income for the fourteen organizations reporting a client on the board was $\$ 2,373,783$. Due to the small sample, the average was skewed because several of the organizations reporting that a client is on the board had higher income than most of the human services nonprofit organizations in the study. The medium measure is most likely a better measure of the overall sample. This phenomenon will be explored further in the discussion of the inferential statistics results below.

A similar sort of skewing phenomenon occurred when the average dollar amount of assets of organizations with clients on boards was calculated. The average was $\$ 4,901,440$, but the range was between $\$ 37,589,452$ and $\$ 0$. Again, the medium appears to be a more appropriate demographic measure. 
As previously noted in the Methodology Chapter, there were two questions in the online Phase I survey focused on whether participating organizations with a client on the board were required to have a client on the board and, if so, why. Only two survey participants responded to the questions. One participant reported that there was no requirement; the other reported that their organization was required to have a client on the board because it was part of the organization's charter. Without specific information on sources of funding, it is not possible to speculate if the sources of funding impacted an organization's decision to have a client on its board.

\section{The number of organizations with clients involved in other potential}

decision-making activities. As Table 6 indicates, nine organizations, or $15 \%$ of the responding organizations, reported that clients held membership in the organization. Over half of the organizations reporting that there was a client on the board also reported that clients held membership in the organization. This is potentially significant because, at least in the past, organizations' members at times elected board members from the membership. 
Table 6

Summary Phase I Survey Responses - Frequency of Client Participation by Activity

\begin{tabular}{lcc} 
Client Participatory Activity & $\begin{array}{l}\text { Number of } \\
\text { Organizations }\end{array}$ & $\begin{array}{c}\text { Percent of } \\
\text { Organizations }\end{array}$ \\
\hline Clients are on Governing Board & 14 & 23 \\
Clients Have Organizational Membership & 9 & 15 \\
Clients are on Advisory Committees & 21 & 34 \\
Clients Participate in Work Groups & 12 & 20 \\
Clients Received Surveys & 31 & 51 \\
\hline
\end{tabular}

In addition to information about membership, Phase I survey data revealed (and Table 6 reports) the following: (a) Clients participated on advisory committees in 21 of the organizations; this figure means that $34 \%$ of the reporting organizations engaged clients as advisory board members. (b) Twelve, or 20\%, of the responding organizations, reported that clients participated in work groups. (Because those participating in the telephone survey had an opportunity to clarify their answers, they sometimes provided additional information. In this case, the majority of the telephone respondents noted that their organizations did not utilize work groups.) See Appendix D for telephone survey questions and responses.

Finally the highest percent of organizations, $51 \%$ or thirty one of the 61 organizations represented in the sample, reported that their clients were able to participate in their organizations' decision-making processes by inviting them to fill out surveys. Most telephone survey respondents once again provided additional information. They 
noted that the surveys clients participated in were satisfaction surveys; some respondents also indicated that their organizations conducted exit surveys and one organization reported pre and post surveys for clients. Once again, see Table 6 for a summary of the results.

Table 7

The Total Number of participatory activities among responding organizations.

\begin{tabular}{ccc}
\hline $\begin{array}{c}\text { Number of Participatory } \\
\text { Activities with Clients Engaged }\end{array}$ & $\begin{array}{l}\text { Number of } \\
\text { Organizations }\end{array}$ & $\begin{array}{c}\text { Percent of } \\
\text { Organizations }\end{array}$ \\
\hline 0 & 17 & 28 \\
1 & 17 & 28 \\
2 & 15 & 24 \\
3 & 9 & 15 \\
4 & 2 & 3 \\
5 & 1 & 2 \\
Total & 61 & 100 \\
\hline
\end{tabular}

As Table 7 indicates, twenty-eight percent of the responding organizations reported that their clients did not participate in any of the identified activities. Of the responding organizations $27 \%$ reported that clients participated in one of the identified activities and $24 \%$ reported that their clients participated in two of the identified activities. The percent of organizations reporting that their clients participate in three of the identified activities was $15 \%$, while only $3 \%$ reported that their clients participate in four of the identified participatory activities. One reporting organization indicated that its clients participated in all five identified participatory activities. The most frequent 
combination of participatory activities was participating in an advisory group and being invited to participate in surveys.

Summary of Research Question \# 1 findings. The data indicated that only 14 of 61 of the responding organizations had members serving on their governing boards. The vast majority of these organizations provided services for specific populations such as the population with HIV/AIDS or persons with disabilities. Additional organizations did engage clients in other organizational activities that presumably might involve decision-making about the organization. The activities included service on advisory committees (34\%), participation in work groups (20\%) and providing feedback to the organization through filling out surveys (51\%). Only $15 \%$ of the responding organizations reported that clients held membership in the organization, however. This is a potentially important figure for this study of clients as board members, because, at least in the past, an organizations' members at times elected board members from the membership the organization.

\section{Answering the second research question}

The study's second research question is: Is there a relationship between the demographics of an organization, to include additional client participatory activities, and having participants of services as voting members of the governing board? Answering this question required the use of binomial logistic regression techniques. With one exception, a small sample size, the data met all of the assumptions for employing a binomial logistic regression. 
The independent variables included various organizational characteristics, i.e., NTEE-CC subsectors, Rule Date (year the corporation was organized as a 501(c)3), 2013 total Assets, 2013 total Income, and 2013 Revenue. The ten NTEE-CC subsectors also were treated as independent variables.

The subsector classification for each responding organization was transformed into a dummy variable (One if the organization was included in the subsector and 0 if the organization was not in the subsector.) Each organization was identified by only one subsector. The three fiscal parameters---assets, income, and revenue-were measured in actual dollar amounts. As stated above, only the year, not the month, was used for the date the organization became a 501(c)3 corporation.

The list of independent variables also included the involvement of clients in nonboard organizational activities that conceivably impact organizational decision-making. These variables included clients holding membership in the organization, participating on advisory boards, being involved in work groups, and being invited to participate in organizational fact finding surveys. Each of these activities were transformed into a series of dummy variables; 1 if a client of the organization was engaged in the activity and 0 if a client of the organization was not engaged in the activity.

This binomial logistic regression model was designed to determine the extent to which select organizational characteristics and types of client participation in potential decisionmaking activities on the board of directors were able to explain the variance in actual board membership among 61 organizations. For this analysis, forward stepwise 
regression techniques were used with the model's 18 independent variables; results revealed that two independent variables: NTEE-CC subsector P80-89 and clients holding membership in the organization were significant at the .01 level. (See Table 8.). The Hosmer and Lemeshow statistic also showed that the model was a good fit with an overall predictive ability of 85 .

Table 8

Regression Output

Variables in the Equation

\begin{tabular}{llrrrrrr} 
Variables & \multicolumn{1}{l}{ B } & \multicolumn{1}{l}{ S.E. } & Wald & df & Sig. & Exp(B) \\
\hline Step 1 & P80-89 & 2.659 & .720 & 13.656 & 1 & .000 & 14.286 \\
& Constant & -2.303 & .524 & 19.280 & 1 & .000 & .100 \\
Step 2 & P80-89 & 2.573 & .785 & 10.732 & 1 & ${ }^{*} .001$ & 13.108 \\
& Membership & 2.260 & .959 & 5.555 & 1 & ${ }^{*} .018$ & 9.583 \\
& Constant & -2.726 & .621 & 19.293 & 1 & .000 & .065 \\
\hline
\end{tabular}

Note. a. Variable(s) entered on step 1: P80-89.

b. Variable(s) entered on step 2. Membership

* Significant at the 0.01 level.

Predicted probabilities. The predicted probability for each of the significant variables was calculated using the following formula: $\mathrm{p}_{\mathrm{i}}=e^{\mathrm{u}} /\left(1+e^{\mathrm{u}}\right)$. First the logit $(\mathrm{u})$ was calculated using the intercept and the beta weight values for the two significant variables: organizations classified as subsector P80-89 and clients of an organization holding membership in the organization. Next Eulers e (2.718) to the power of the logit divided by 1 plus 2.718 to the power of the logit was calculated, resulting in the predicted probability for all combinations of the significant variables. 
The predicted probability of an organization in the P80-89 subsector having a client on the board of directors and holding membership in the organization was 89 percent. For this sample of organizations, the probability of an organization classified in the NTEE-CC subsector of "P80-89," i.e., having a client who holds membership in the organizations, and is on the board of directors is 82.9 percentage points greater that an organization in the NTEE-CC subsector not having a client not holding membership and not on the board. See Table 9 for predicted probabilities for all possible conditions.

Table 9.

Predicted Probability

Condition o organizations in subsector P80-89

Client not holding membership and not on the board of directors

Client holding membership and not on the board of directors

Client not holding membership and on the board of directors

Client holding membership and on the board of directors
Predicated Probability

0.061

0.385

0.46

0.89

\section{The Phase II Data}

Answering the third question. The third research question (Is there a

relationship in the level of engagement between client and non-client board members on the same board?) and the fourth (What are the perceived experiences of clients and nonclients?) were to be answered by a new set of data generated by a second survey and by analyzing meeting notes or minutes. The plan was to have individual board members of organizations that had clients on their boards and that volunteered to participate in the 
second phase of the study complete a second survey that would reveal how both clients and non-clients on the same board felt about their experience as a board member.

The administration of the survey was to be followed by a review of the participating organization's board meeting minutes for the most recent twelve months. The indicators of participation were: serving as the president of the board, serving as another board officer, attendance at meetings, making a motion, seconding a motion, asking questions, serving as the chair of a standing or ad hoc committee, and serving on a standing or ad hoc committee.

Phase II survey results. Unfortunately, only two organizations agreed to participate in the Phase II survey. Both organizations had reported in the Phase I survey that there was a client on their board of directors. The executive directors were asked to email the survey link along with a brief explanation of the study to all of the board members of their organization. As noted previously, this approach was designed to allow respondents to remain anonymous.

In fact the board members from only one of the organizations, here given the pseudonym ORG-A, responded to the survey. Six individual board members from ORG-A completed the survey. The second question of the survey provided an opportunity for the respondents to identify themselves as a person receiving services from the organization. None of the ORG-A respondents, however, selected "Yes" when asked if they received services from the organization. Because of the lack of data, I was not 
able to examine if there were any differences between the perceived experiences of the one client and the non-clients on the same board.

It is not clear why so few organizations agreed to participate in the second phase of the study, why only one of the two organizations that agreed to participate actually participated, and why the client member of the board of the participating organization did not identify herself or himself. The result of all of these factors was and is obvious, however: The survey responses were useless in determining how clients and non-clients perceived being a member of the board. I was left with only the option of analyzing minutes that were available to the public to generate insights about the actual activities of client and non-client board members. The results of this analysis - which could provide an answer to Question 3 for the two organizations whose notes were analyzed but, of course, not Question 4-will be presented in the next subsection.

Review of document analysis procedures. Meeting notes or minutes for three separate organizations were available for review. Two of the three organizations, here called ORG-A and ORG-B, had agreed to participate in Phase II of the study (although only ORG-A board members actually completed the Phase II survey). The third organization, ORG-C, had reported in the Phase I survey that it had two clients on the board, but the Phase I survey respondent from the organization declined to participate in the second phase of the study. ORG-A provided email copies of the most recent twelve months of board meeting notes. ORG-B and ORG-C's board meeting notes/minutes were publicly available on their respective websites. The notes/minutes covered a total of 32 hours of board meeting time over the 12 month period prior to the review. 
Data were to be tabulated and compared for both client and non-client board members' participation in the following activities:

1) Number of meetings attended

2) Number of times asking questions

3) Number of seconds to motions

4) Number of motions made

5) Participates on a committee

6) Chaired an Ad Hoc committee

7) Chaired a standing committee

8) Serves as a board officer

9) Serves as board president

It should be noted that none of the board meeting notes reviewed provided any information about which board members asked questions nor was there information about committee membership. Only committee chair persons were identified.

Document review results. As it turned out, the client board member was not identified in ORG-A minutes/meeting notes. Consequently, a comparison between what the client board member did and what other board members did could not be made. The document review, in other words, was no more helpful than the ORG-A survey results for comparing the activity levels of client and non-client board members. 
Fortunately, client board members for both ORG-B and ORG-C could be identified. Consequently, I analyzed online board meeting notes/minutes for a twelvemonth period for both organizations.

ORG-B. ORG-B's board met quarterly. Each ORG-B board meeting was approximately two hours in duration and occurred in the early evening. The client was identified because there is a specific position on the board reserved for a "Community Representative-Client."

The ORG-B Board of Directors was a fluid board. It appeared that some board members served because they were representing the interest of other organizations which appeared to be operating seasonally. Due to confidentiality concerns, no additional information regarding the seasonally operating organizations can be revealed here. Because the other organizations that client board members appeared to represent operated only during specific times of the year, board members would leave at the end of one season and another individual would come on the board at the start of the next season. Occasionally it appeared that the same person returned, but several times during the twelve months, new people came on the board to fill vacated positions. There did not appear to be a vote taken when someone new came on the board, but it did appear that they were accepted as a representative of a specific organization and, consequently, as a member of the board. 
In short, this board operated much like an association in which it is expected that each member organization send a representative to board meetings. However, this organization was not identified as an association.

I tabulated the board activities identified above for each of the board members. Over the course of twelve months two different clients filled the client position on the board. To estimate client participation, the frequencies of their participatory activities were combined. There was a total of twenty three board members eligible to attend over the course of four board meetings. Two of the twenty-three board members were absent from all of the meetings. On average, board members attended 2.6 quarterly board meetings over a 12 month period of time. Only two board members attended all four board meetings. Five board members attended only one meeting, five board members attended two meetings, five board members attended three board meetings, and three board members attended four board meetings. The two clients collectively attended all four of the board meetings.

There were ten standing committees, each chaired by a board member. Neither client chaired a standing committee nor did either client hold a board officer's position. However, one of the clients was chair of an ad-hoc committee.

The board meetings were a combination of consensus and majority vote. There was an average of four motions and seconds made during each board meeting. Neither client made any motions but one of the clients made four seconds to motions over the course of the three board meetings this particular client attended. The board meeting 
notes did not reflect who was asking questions, so it was not possible to determine if the client was actively engaged in this particular way. One client held the chair position for one Ad hoc committee and made a presentation at two separate times on the progress of the Ad Hoc committee.

Overall, client composite board meeting attendance was slightly higher than the average of 2.6 meetings attended by each board member. Most of the motions and seconds seemed to be typical of the majority of ORG-B board members excluding the most prolific motion and second makers.

Given that the client position seemed to be related to seasonal operation of the organization they were representing, it probably is not surprising that clients did not hold an officer's position, as that position would go unfilled during certain times of the year.

On the surface, therefore, it did appear that the client's profile of participation was similar to the participation profile of the majority of non-client board members. But it must be noted, this was a board that appeared to be in a constant state of flux, and, consequently, it is not possible to use this organization to generate even a grounded hypothesis about what will occur in more typical organizations with clients on boards.

$\boldsymbol{O R G} \boldsymbol{C}$. As has already been noted, the ORG-C representative reported in the Phase I survey that there were two clients serving on their board of directors. I reviewed notes from eleven meetings each approximately one and a half hours in duration. The meetings were held early evening in Central San Diego. There also was an annual 
membership meeting held, but the notes were in a different format and attendance and motions were not discernable.

The average number of board members at each meeting was approximately nine. The average number of board meetings attended by each board member was eight and a half. Range of attendance was one to eleven. Three board members attended all eleven meetings. There were two board member positions that changed during the document review period. There were an unspecified number of standing and Ad Hoc committees. Not all the committees were chaired by board members.

Because ORG-C is required by law to maintain confidentiality about service recipients, the clients on the board were not specifically identified in the publicly posted meeting notes/minutes. However, because there is another legal requirement that all nonprofit board members must disclose a conflict of interest, the two clients were identified in the board meeting minutes by their initials as having a conflict of interest. And because they were the only board members whose conflict of interest was not described, it was easy to match initials with names and identify which board members also were clients.

One of the two clients was on-leave for all but three of the board meetings. The second client attended nine board meetings. This client's attendance was above the average. I suspect that this client's attendance would have been higher, except, as noted in the board meeting notes, this client experienced a personal tragedy which led to missing a meeting. 
There were a total of thirty nine motions and seconds made during the document review period, with an average number of motions and seconds of four per meeting. Slightly over 40 percent (sixteen) of all motions were attributed to one board member. Just under 40 percent (fifteen) of all seconds were attributed to another board member. Clients were responsible for making 7.6 percent of all motions and seconds, which was slightly above the average for all board members.

There were a total of five officers positions held by board members. One of those positions was held by a client. Two board members held the board chair position and neither of them were clients.

Overall it appears that the clients of ORG-C were as active in the board as most of the other board members. The board meeting notes also reported on several activities outside of the board meetings. Based on these community reports, the clients had also been involved in advocacy efforts on the part of the population of people they represented. For ORG-C board meeting data see Appendix G.

Document review summary. The board meeting notes/minutes for three organizations, ORG-A, ORG-B, and ORG-C, were reviewed, totaling 32 hours of notes/minutes reviewed. The notes/minutes for ORG-A were not useful for answering Question \# 3 because the client member of the board could not be identified. The analysis of the meeting notes/minutes for ORG-B also was somewhat problematic because of the fluid membership of client members, though data about client participation versus the participation of other clients were generated. It was possible to identify the 
two clients who served on the board of ORG-C, and coding of client and non-client board members activities was relatively easy for this organization.

The findings from Phase II of the study, though modest in scope, are at least somewhat encouraging. In the two organizations in which client board members could be identified, it did not appear as if client's service on the boards were merely procedural display. Client board members appeared to be at least as actively engaged in board meeting activities as most non-client members were. Especially when confounding factors such as seasonal participation were factored in, clients' profiles of activities looked like the profiles of most non-client board members.

Of course, the number of organizations' minutes that were analyzed was exceedingly small, so it is impossible to know for certain whether clients and non-client on boards behave or are likely to be treated differently. Still, the fact that, in one organization, one client outperformed some non-client board members and another client's participation was much more limited than most client members of the board suggests that the personal characteristics of client members may be more important than their role as client board members in determining their levels of participation. The level of participation, in short, could very well be a function of each individual's unique characteristics and personality and may have little or nothing to do with whether they are clients or non-clients. 


\section{CHAPTER 5}

\section{DISCUSSION}

This final chapter will begin with brief discussions of the impetus of this study and the methods employed. Then the findings will be briefly reviewed and compared to findings from similar research. In this chapter I also will consider why I obtained only limited data on the experiences and perceptions of clients on nonprofit human services boards of directors. The chapter concludes with discussions of the study's significance and limitations and comment about related research that needs to be conducted in the future.

\section{The Impetus for the Study}

Nonprofit corporations' boards of directors have been in existence in the United States for nearly a century. For-profit and nonprofit board composition started to garner

attention in the last quarter of the $20^{\text {th }}$ century due to highly publicized corporate scandals involving fraud and corruption. In light of all the discussion and frequent suggestions that clients can bring benefits to organizations by participating on organizations' boards of directors, it is surprising that empirical data on nonprofit board composition inclusive of clients is nearly nonexistent. The need to understand the extent to which clients were serving on nonprofit organization boards (in particular in the human services area) where clients presumably could provide valuable information, from a client's perspective, to board decision-making, was the impetus for this study. There also appeared to be a need 
to study the factors that were associated with having clients on the boards of nonprofit organizations in the human services domain.

\section{Methods Employed in this Study}

This study was designed to be conducted in two phases. Phase I was focused on gathering empirical data through a survey of representatives of nonprofit organizations in the human services domain on the prevalence of clients on the boards of directors of human services organizations they receive services from in one county in the United States. Survey data was gathered both online and by telephone. Survey responses were collected from sixty-one organizations either through an online or a telephone survey. In addition to calculating the percentage of organizations with clients on board and that also had clients involved in other organizational activities that presumably are associated with organizational decision-making, binomial logistic regression was used to determine factors associated with having clients on boards.

Phase II of the study was designed to use a second survey, i.e., an individual board member survey, as well as a document review of the most recent 12 months of board meeting minutes/notes, to gain a better understanding of the client's experiences as compared to the non-client experiences on the same board. For reasons that will be discussed below, the document review provided limited information on the client's level of participation compared to non-client participation on the same board, and attempts to gather individual board member survey data failed almost completely. 


\section{Findings}

\section{Research Questions One and Two}

The first phase of the study was used to answer the first two research questions. Research Question \#1 was: How many human services nonprofit organizations in San Diego County include people who receive services on their board of directors; what are the types of services and the fiscal characteristics of organizations with clients as board members; and how many organizations involve clients in other activities that potentially involve decision-making about the organization? Research Question \# 2 was: Is there a relationship between the demographics of an organization, to include additional client participatory activities, and having participants of services as voting members of the governing board?).

Sixty-one organizations responded to the Phase I survey either online or during a telephone interview. Fourteen, or 23 percent, of the responding organizations reported that they had at least one person who was receiving services from the organization on their board of directors.

Respondents also were asked about whether clients participated in other activities that presumably could impact organizational decision-making. Of the 61 responding organizations, $21(34 \%)$ reported that there were clients participating in advisory committees, $12(20 \%)$ reported clients participated in work groups, and 31 (51\%) reported that clients were invited to participate in organizational fact finding surveys. In 
addition, 15 percent of the organizations indicated that clients also held membership in the organization.

Binomial logistic regression modeling was employed to examine the relationship between specific organizational characteristics and the presence of clients on the board of directors for the organization serving them. In addition to examining the organizations characteristics, I also examined the relationship between specific types of organizations, based on their National Taxonomy of Exempt Entities Core Codes (NTEE-CC) subsector, and the frequency of clients engaged in potential decision-making activities other than being a board member, and the presence of clients on the board of directors. The dependent variable throughout the analysis was the presence of a client on the board of directors.

Two of the eighteen independent variables were significant at the 0.01 level. Organizations with a client on their board of directors were more likely to be in the (NTEE-CC) subsector P80-89, Centers to Support the Independence of Specific Populations, and are more likely to have clients with membership in the organization.

\section{Research Questions Three and Four}

Research question three (Is there a relationship in the level of engagement between client and non-client board members on the same board?) was answered through a careful review of two organizations' board meeting minutes/notes for the months of March 2015 through February 2016. These data, although extremely limited, did suggest that at least some clients on the board of a human services organization that also included 
non-clients participated at approximately the same level as any other member on the board.

Question four (What are the perceived experiences of clients and non-clients?) was designed to capture information about the perceptions of the board members on a nonprofit board with both clients and non-client. This question remains unanswered. Nearly all of the 61 responding organizations declined to participate in the individual board member survey that was to be a major feature of the second phase of the study. Only three organizations agreed to participate, and, of those three, only one sent the survey out to their board members. Of the six people completing the survey, no one identified themselves as a client. Consequently, the fourth question could not be answered even with a less-than-adequate response rate.

\section{A Comparison of This Study's Findings to the Findings of Previous Research}

There was only one other study, a study conducted by LeRoux (2009), that focused on the presence of clients on nonprofit boards. LeRoux reported a higher percentage (forty-nine percent) of organizations with clients as board members. My research was constrained to not only one geographic area but also to a narrow range of nonprofit organizations, Human Services Organizations (NTEE-CC P01-P99). These differences may explain, in part, why my study yielded a smaller number of organizations with clients on the board than LeRoux's 2009 study. LeRoux studied a broader category of nonprofit organizations, social service organizations, not simply a specific NTEE-CC subsector. 


\section{Why the Lack of Success?}

As a researcher, the low response rate to the Phase I survey, along with nearly all of the organizations with clients on the board declining an invitation to participate in Phase II of my study, was a deep concern. As a nonprofit practitioner for over 40 years, perhaps I should have been able to predict what occurred when I attempted to implement my two- phase research design. But I did not anticipate the Phase II response rate problems that occurred, and naively hoped and believed the response rate would be high.

What I should have realized is that human Services organizations are required, by law, to protect the identities of the people they serve. In spite of the fact that the Phase I survey had a guarantee of participant confidentiality and the Phase II survey had a guarantee of anonymity for participants, I believe there is still a great deal of angst about the possibility of breaching the legal requirement not to reveal the identities of clients. I also am not sure how many people understand the difference between confidentiality and anonymity.

There are strict laws regulating client confidentiality. Moreover, there are even stricter laws prohibiting many marginalized and vulnerable clients from becoming participants in research.

People in general must give informed consent to participate in any kind of research. There are many people who believe marginalized and vulnerable people with limited resources cannot actually provide informed consent. Consequently, for some specific populations, research is strictly prohibited. The laws governing clients of human 
services organizations were enacted as a result of serious pain and injury being inflicted on entire populations of vulnerable people in the name of research.

Hitler euthanized 200,000 people identified as impaired between1940 and 1945; he was convinced impaired individuals would infiltrate the Aryan genetic pool. (United States Holocaust Memorial Museum, 2016). Although this is an extreme example there are many more stories that have been passed from one generation to the next and from person to person that have resulted in great mistrust of people conducting research.

Closer to home, from 1932 until 1972 when the study was halted, hundreds of African American men were allowed to go untreated after being diagnosed with syphilis and in some cases even prevented from obtaining treatment. Throughout the duration of the study, the men were lied to and told they were receiving treatment (Centers for Disease Control, 2016).

All of these examples suggest that it is understandable why human services organizations may not have been inclined to have their clients participate in research. The problem also may have been compounded by the fact that my survey was an online survey rather than the mail in survey approach used by LeRoux (2009).

For example, in 2012 Time's (Ho, 2012) online magazine published the results of a survey asking people if they trusted the internet. Ninety-eight percent said, "No." Some of the reasons they gave were: worried "bad things" would happen, a waste of their time, their computer might get a virus, or, worse yet, they might become a victim of fraud. 
For many, the legacy of mistrust of research is pervasive. Mistrust, along with concerns regarding informed consent and confidentiality, would certainly have caused my practitioner (as opposed to my researcher) self to be reluctant to participate in the Phase I survey, and most likely would have prevented me from participating in the Phase II survey.

In short, I realized that I had failed to bring my practitioner's perspective to my research. I should have been able to predict, from my own experiences, that human services organizations would respond the way they did, i.e., deciding not to participate.

In 40 years of service I might have completed, at most, two surveys and, then, only because I had a professional relationship with the person making the request. I never felt that I had the time to answer questions. I did try to keep in mind, when I designed the surveys for my study, that most people will not complete long surveys. My first goal in developing the Phase I survey, in fact, was for it not to take more than 5 minutes to complete. I believe I achieved my first goal. The average length of time to complete the survey was less than 3 minutes. The length of the survey, therefor, did not seem to be the cause of nonparticipation in this case. Other issues, undoubtedly, were more salient. One of these issues was the matter of confidentiality. Whenever I was asked to participate in research, maintaining confidentiality for the people I served was always foremost in my thinking. Although, the Phase I survey appears to be fairly innocuous, just the word research would raise a red flag for me. 
Furthermore, it was not just the legal considerations with regard the maintaining confidentiality but also the potential for other potential negative consequences. Research always seems to snowball. One minute the researcher is looking at clients on the board and the next minute they're examining your financial statements. Even the most diligent executive director might have been afraid that something potentially damaging would be revealed. A concern for damage control was always present. Indeed, anyone who has participated in a regulatory audit has experienced this phenomenon.

There was at least one other issue why my practitioner self would likely not have participated in this study (and why, I believe, others opted out of participating): I frequently did not see any direct benefit to my organization, and felt I couldn't take the time away from the day to day activities.

If the practitioner version of me had decided to participate in the Phase I survey, I most certainly would not have participated in the Phase II. I would have felt uneasy if the board members, essentially my employers, were asked to share their experiences as board members. I, of course, would have requested to see the results. Even though the executive director is not directly responsible for the actions of the board, many executive directors are on their boards of directors and have been deeply involved in recruiting new members. It seems reasonable that many executive directors would be reluctant to know how their board members perceive their experiences.

The Phase II survey had even more complications that my practitioner self would have duly noted. Even though, I offer in the survey instructions to provide a paper copy 
of the survey, and I did not build in any time constraints with regard to when the surveys would need to be completed, the logistics of the Phase II were still too complicated. To begin with, I would have felt compelled to discuss the survey with all the board members before sending it out to them just to make sure they clearly understood the survey was optional. This discussion would most likely occur during a board meeting. Many nonprofit organizations meet quarterly so in some cases it could be as long as three months before the survey would be discussed. After three months the survey would have been most likely been forgotten.

Additionally, several of my board members did not have easy access to a computer and would most like have had difficulty reading the survey. As the executive director and not a board member, I would have been very uncomfortable assisting a board member in completing the survey. The board members might have needed to find someone to help them.

It was not just the survey part of Phase II that was problematic; a review a 12 months of board meeting notes also would have been too time consuming. My organization did have someone paid to take notes, the notes were keep in a specific location, and they were electronic. However, all the board correspondence was centrally located. Sorting through and separating out only the notes would have taken time.

Furthermore, it has been my experience that frequently note taking is a voluntary activity and in an effort to make note taking tolerable the task is sharing among board members. Generally, voluntary note taking results in inconsistent information being 
recorded. Frequently note takers seem nervous about their ability to spell which results a reluctance to share the notes. All of these factors potentially contribute to a delay of notes being published and in some instances never published. Even with the best of intentions some board meeting notes just never surface.

Again, the general fear of research and the snowball effect would have prevented me from participating in the Phase I survey. The logistics of the Phase II survey were too complicated and time consuming. I would not have been able to justify the time or effort to participate in the survey. All of this seems quite clear in retrospect. I wish my practitioner-self had surfaced sooner and impacted the design of the study.

\section{Implications}

The fact that the vast majority of human service organizations with clients on their boards of directors were oriented toward promoting independence among their clients is hardly surprising since involvement in board activities could be seen as a way of encouraging independence. Furthermore, some organizations in the human services areas, other than P80-89, really could not have clients as board members. An obvious example are organizations providing hospice services, these organizations are helping people die with dignity.

Still, given the extensive discussion over the past decades about the value of engaging recipients of services in decision-making about the services provided, it is somewhat surprising that the findings in this study, at least, were so skewed toward organizations that have as their mission the promotion of independence. It seems likely 
that clients could contribute to board decision-making in other types of organizations, as well.

\section{Future Considerations}

I am convinced that empirical data about perceived experiences of clients as board members - i.e., the sort of data I wanted to collect as part of this study but was not able to gather-could be valuable for nonprofit leaders. Empirical data has the potential to provide leaders of nonprofit organizations information about how to better support clients on boards. If clients are able to fully participate and contribute knowledge about the benefit or lack of benefit and utilization of services, leaders would have a powerful tool to aide in improving services. Allowing organizations to derive greater benefit from client participation in the decision-making processes would also have the added potential benefit from clients becoming involved in the democratic process and developing the skills needed to become self-advocates.

Future research will most assuredly need to be qualitative in nature and be approached in a culturally sensitive manner. Human Services organizations have historically served marginalized populations. Both the leaders and the clients of these organizations have very little reason to trust an outsider conducting research. Gathering information about board members perceived experiences has the potential to be very threatening to the leader of the organization. Face to face introductions and conversations with the opportunity to gain trust would most likely hold the greatest potential for future research. 
Moreover, future research should be designed to study nonprofit organizations that have integrated the people they serve into decision-making positions with real power. As Arstein (1969) has pointed out, no one has a greater interest in quality services that support people in becoming more successful than the people receiving those services. By gathering and sharing intimate knowledge from organizations that have benefited from including clients in the decision-making processes of the organizations, other organizations might see the value and adopt the same practices.

\section{Significance, Limitations, and Delimitations}

\section{Significance}

Insights generated by this research can serve to inform the leaders of nonprofit organizations about the importance and practicality of adopting an inclusive approach to having primary recipients of services participating on governing boards and may, in fact, encourage more organizations to include clients on boards. Specifically, the study indicates that, among Human Service organizations participating in the study, only $14 \%$ had client as voting board members. This study also suggested that the presence of clients on boards was skewed toward a particular type of nonprofit organization: human service organizations encouraging independence for specific populations. Based on the results of this study, it appears that human service organizations of all types are more likely to include clients in activities that have the potential to impact organizational and programmatic decisions other than board membership.

Although the data in this study was limited, it appears as if clients have to same potential for participation in board activities as non-client board members on the same 
board have. This study, in short, suggests both that clients serving as board members may be quite limited and that there is no compelling reason that the number of clients serving on boards should be so low.

\section{Limitations}

Having written what I did about the potential significance of this study, I also must quickly acknowledge that the study's small sample size is clearly a barrier to generalizing findings. In addition, the sample is a convenience sample and limited geographically to one region of the country. Also, a response rate of 22 percent is relatively low, though the test for nonresponse bias suggested that this may not be a problem.

In addition, participants, although randomly selected from a pool of potential organizations, ultimately self-selected to participate in the study. In other words, there is no guarantee that those organizations and individuals that chose to participate in the study are similar to those that chose not to participate. Of course, if selection effects were a part of this study, it seems likely that they might have inflated data about the number of organizations with clients on boards. I say this because it seems likely that organizations with clients as board members would be more inclined to fill out the survey than those organizations that do not have clients on boards.

\section{Delimitations}

The study examined only human services organizations in one county. Human services organizations were chosen because of all the various types of nonprofit organizations, human services organizations held a greatest possibility that there might be 
a client serving on the board of directors specifically because they represent the population of people served. 


\section{References}

Abzu, R. (1996). The Evolution of Trusteeship in the United States: A Roundup of Findings from Six Cities. Nonprofit Management and Leadership. 7(1), 101-111.

Arnstein, S. (1969). A Ladder to Citizen Participation. Journal of the American Institute or Planners, 35(4), 216-224.

Bradshaw, P. (2009). A Contingency Approach to Nonprofit Governance. Nonprofit Management \& Leadership, 20(1), 61-81. doi: 10.1002/nml.241

Bradshaw, P., Murray, V., \& Woldpin, J. (1992). Do Nonprofit Board Make a Difference? An Exploration of the Relationships Among Board Structure, Process, and Effectiveness. Nonprofit and Voluntary Sector Quarterly, 21, 227. doi: 10.1177089976409202100304

Boris, E., Leon, E., Roeger, K., \& Nikolova, M. (2010). Human Service Nonprofits and Government Collaboration Finding from the 2010 National Survey of Nonprofit Government Contracting and Grants. Urban Institute Center on Nonprofits and Philanthropy.

Brown, W. (2003). Inclusive governance practices in nonprofit organizations and implications for practice. Nonprofit Management \& Leadership, 12(4), 369-385. doi/10.1002/nml.12404/pdf

Brudney, J. L., \& Murray, V. (1998). Do intentional efforts to improve boards really work? The views of nonprofit CEOs. Nonprofit management and leadership, 8(4), 333-348. doi: 10.1002/nml.8403

Bun, K. (2001). The Salt Merchants of Tianjin State Making and Civil Society of Late Imperial China. University of Hawai'i Press, Honolulu. Retrieved from http://scholarspace.manoa.hawaii.edu/bitstream/handle/10125/23059/\%2353_Loa n.pdf? sequence $=1$

Burger, J., \& Cooper, H. (1979).The Disability of Control. Motivation and Emotion, 3(4), 381-393. Retrieved from https://www.scu.edu/media/college-of-arts-andsciences/psychology/documents/Burger-Cooper-ME-1979.pdf

Carmen, J. (2011). What you Don't Know Can Hurt Your Community Lessons From a Local United Way. Nonprofit Management \& Leadership, 21(4), 433-488. doi:10.1002/nml.20035 
Community Tool Box (2014), Work Group for Community Health and Development at the University of Kansas. Retrieved from http://ctb.ku.edu/en/table-ofcontents/structure/organizational-structure/train-board-of-directors/main)

CRS Report to Congress, 2005.Retrieved from http://www.nationalaglawcenter.org/assets/crs/RS22286.pdf

Centers for Disease Control (CDC), (2016). U.S. Public Health Service Syphilis Study at Tuskegee. Retrieved from http://www.cdc.gov/tuskegee/timeline.htm

(Deitrick, L., Roberts, T., Jones, J., Krasynska, S., Lewis, E., Kahl, S., \& Libby, P., (2013). Annual Report State of Nonprofits. Retrieved from http://catcher.sandiego.edu/items/soles/061113_USD_StateNonprofits_Spring201 3Report_FINAL.pdf

Eisinger, Peter K. 1982. Black Employment in Municipal Jobs: The Impact of Black Political Power. American Political Science Review 76(2): 380-92. Retrieved from http://0www.jstor.org.sally.sandiego.edu/stable/1961117?seq=1\#page_scan_tab_contents

Freeman, R.E. (2002). The stakeholder approach revisited. Zeitschrift für Wirtschafts und Unternehmensethik, 5(3), 228-241. Retrieved from http://www.zfwu.de/fileadmin/pdf/3_2004/Freeman_HansenBodeMossmeyer.pdf

Gazley, B., Chang, W., \& Bingham, L. (2010). Board diversity, stakeholder representation, and collaborative performance in community medication centers. Public Administration Review, 70(4), 610-620. doi/10.1111/j.15406210.2010.02182.x/pdf

Guidestar, (2013). Which Causes Do Most Nonprofits Serve? Retrieved from http://www.guidestar.org/ViewCmsFile.aspx?ContentID=5025

GuideStar, 2014. A Nonprofit Board's Fiduciary Responsibility. [Web log comment]. Retrieved from http://trust.guidestar.org/2014/10/17/a-nonprofit-boards-fiduciaryresponsibility/

Herman, R. \& Meimovics, R. (2006). The Effective Nonprofit Executive: Leader of the Board. Nonprofit Management and Leadership, 1(2), 167-180. doi: $10.1002 / \mathrm{nml} .4130010207$ 
HIV/AIDS Bureau, Division of Metropolitan HIV/AIDS Programs \& Division of State HIV/AIDS Programs National Monitoring Standards for Ryan White Part A and Part B Grantees: Universal - Part A and Part B, p.1. Retrieved from http://hab.hrsa.gov/manageyourgrant/files/universalmonitoringpartab.pdf

Ho, E., (2012, July 23). Almost Everyone Doesn't Trust the Internet. Time. Retrieved from http://newsfeed.time.com/2012/07/23/almost-everyone-doesnt-trust-theinternet/

Internal Revenue Service (IRS) General Instruction (2014). Retrieved from http://www.irs.gov/pub/irs-pdf/p4220.pdf

Internal Revenue Service (IRS) (2014a). Applying for 501(a)(3) Tax Exempt Status. Publication 4220 Catalog Number 37053T Department of the Treasury Internal Revenue Service. Retrieved from www.irs.gov

Internal Revenue Service (IRS) (2014b) Charities-\&-Non-Profits/Form-1023. Retrieved from http://www.irs.gov/Charities-\&-Non-Profits/Form-1023:-Purpose-ofConflict-of-Interest-Policy

Internal Revenue Service (IRS) (2016) Filing Requirements. Retrieved from https://www.irs.gov/Charities-\&-Non-Profits/Churches-\&-ReligiousOrganizations/Filing-Requirements

LeRoux,, K. (2009). Paternalistic or Participatory Governance? Examining Opportunities for Client Participation in Nonprofit Social Service Organizations. Public Administration Review, 69(3), 504-516. Retrieved from http://academic.evergreen.edu/curricular/atpsmpa/LeRoux\%20parternalistic\%20o r\%20paticipatory\%20gov\%20in\%20npos.pdf

Masaoka, J. (n.d) Nonprofit Conflict of Interest: A 3-Dimensional View. Blue Avocado. Retrieved from http://www.blueavocado.org/content/nonprofit-conflict-interest-3dimensional-view

McDougle, L., Deitrick, L., Libby, P., \& Donmoyer, R., (2008). The Appreciated Sector: Public Confidence in San Diego County Nonprofit Organizations. Retrieved from https://4good.org/usd-nonprofit/the-appreciated-sector-public-confidence-in-sandiego-county-nonprofit-organizations

Mitchell, G. (2013). The Construction of Organizational Effectiveness from Leaders of International Nonprofits in the United States. Nonprofit and Voluntary Sector Quarterly, 42(2), 324-345. doi: 10.1177/0899764011434589. 
Miller, J. (2003). Understanding the Behavior of Nonprofit Boards of Directors: A Theory-Based Approach. Nonprofit and Voluntary Sector Quarterly, 32(4), 521547. doi: 10.1177/0899764003257463

Miller, J. (1999). Perspectives on Nonprofit Board Diversity. Board Source E-Book Series. Retrieved from http://networks.seepnetwork.org/pppdesign2/doc/Perspectives_on_nonprofit_board_Diversity.pdf

Murray, V. (1996). Improving Board Performance. The Philanthropist, 13(4) 3-37. Retrieved from http://www.ufv.ca/Assets/BC+Centres+(CRIM)/NonProfit+Development/Articles/Board+Governance+and+Leadership/Improving+B oard+Performance.pdf

NCCS (2010). Urban Institute, National Center for Charitable Statistics web-based data set. Retrieved from http://nccs.urban.org

NCCS, NTEE Definitions, Retrieved from http://nccsweb.urban.org/PubApps/nteeSearch.php?gQry=allMajor\&codeType=N TEE

NCCS (2016). National Taxonomy of Exempt Entities. Retrieved from http://nccs.urban.org/classification/ntee.cfm

Ramos, N. \& Andersen, T. (2014, November 26). Boston Globe. Retrieved from http://www.bostonglobe.com/metro/2014/11/26/boston-ferguson-protestors-wantleaders-listen-not-speak/zfXLeKLIBEppDJipHThyqN/story.html

Robbins, K., (2006). The Nonprofit Sector in Historical Perspective Traditions of Philanthropy in the West. In Powel, W.W. \& Steinberg, R. (Eds.), The nonprofit sector: A research handbook (pp. 13-31). New Have, CT: Yale University Press.

Salamon, L. (1995). Partners in Public Service: Government-Nonprofit Relations in the Modern Welfare State. Baltimore: Johns Hopkins University Press.

Salamon, L., (1999). America’s Nonprofit Sector: A Primer. Foundation Center, Abridged Online Books. Retrieved from http://foundationcenter.org/getstarted/onlinebooks /salamon/ text.html

Sarbanes Oxley Act 2002. Retrieved from http://www.soxlaw.com/

Schalock, R. (2002). Definitional Issues. In R.L. Shalock, P.C. Baker, \& M.D. Croser (Eds.), Embarking on a New Century. Washington, DC: American Association on Mental Retardation. 
Steckler, A. \& Herzog, W. (1979). How to keep you mandate citizen board out of your hair and off your back: A guide for executive directors. American Journal of Public Health, 69(8), 809-812. Retrieved from http://ajph.aphapublications.org/cgi/reprint/69/8/809

Sulek, M. (2010), On the Classical Meaning of Philanthrôpía. Nonprofit and Voluntary Sector Quarterly, 39(3), 385-408. Retrieved from http://nvs.sagepub.com

Teltsch, K., (1986, November 18). Studying Philanthropy, New York Times, Science. New York Times. Retrieved from http://www.nytimes.com/1986/11/18/ science/studying-philanthropy.html

United States Department of Health and Human Services the Office of Community Services (2004). Retrieved from http://www.hhs.gov/regulations/

United State Housing Act of 1937. In Federal Register Rules and Regulations (1999), 64, 203, 56879. Retrieved from http://www.hud.gov/offices/pih/publications/fedreg/27301.pdf

United States Holocaust Memorial Museum, (n.d.) Retrieved from https://www.ushmm.org/outreach/en/article.php?ModuleId=10007683

Welch, S. \& Bledsoe, T. (1988). Urban Reform and Its Consequences: A Study in Representation. Chicago: University of Chicago Press 


\section{APPENDIX A}

\section{Phase I survey}




\section{Phase I survey}

Note: This is the final version of the survey. After the first distribution the word "Optional" was added to questions 4 through 10.

Participatory Governance: A Mixed Methods Examination of San Diego County Human Services Organizations

\section{l. Purpose of the research study}

I am a doctoral candidate in the School of Leadership and Education Science at the University of San Diego. You are invited to participate in a research study I am conducting. The purpose of this research study is: To understand the level of client participation in the decision-making process of nonprofit human services organizations in San Diego County.

\section{What you will be asked to do}

This survey is the first phase of my research. This survey will help in understanding the level of participation of clients in the decision-making process of nonprofit human services organizations in San Diego County.

Your participation in this survey will take less than 5 minutes.

\section{Foreseeable risks or discomforts}

This study involves no more risk than the risks you encounter in daily life.

\section{Benefits}

While there may be no direct benefit to you from participating in this study, the indirect benefit of participating will be knowing that you helped researchers better understand participatory governance in nonprofit organizations.

\section{Confidentiality}

Any information provided and/or identifying records will remain confidential and kept in a locked file and/or password-protected computer file in the researcher's office for a minimum of five years. All data collected from you will be coded with a number or pseudonym. Your real name and the actual name of the organization you represent will not be used. The results of this research project may be made public and information quoted in professional journals and meetings, but information from this study will only be in aggregate.

\section{Compensation}

You will receive no compensation for your participation in the study.

\section{Voluntary Nature of this Research}

Participation in this study is entirely voluntary. You do not have to do this, and you can skip any question or quit at any time. Deciding not to participate or not answering any of the questions will have no effect on any benefits you're entitled to, like your health care or your employment. You can withdraw from this study at any time without penalty.

\section{Contact Information}

If you have any questions about this research, you may contact either:

\section{1) Elaine Lewis}

Email: elaine.lewis@sandiego.edu

Phone: 619-971-2801

2) Dr. Robert Donmoyer Email: donmover@sandiego.edu 


\section{Phone: (619) 260-7445}

I have read and understand this form, and consent to the research it describes to me. I may print a copy of this consent form for my records.

\section{Please check one,}

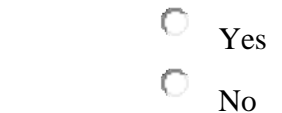

\section{If No Is Selected, Then Skip To End of Survey Skip Logic}

\section{Q2}

Please provide your organization's EIN number or the legal name of the organization?

\section{Q3}

Your position with the organization?

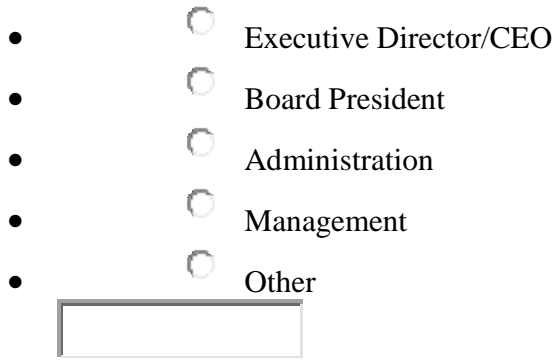

If Executive Director/CEO Is Not Selected, Then Skip To What gender does the executive direct..

Q4

What gender do you identify as? (Optional)

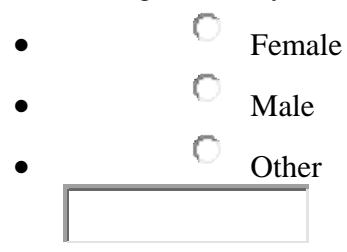

\section{Q5}

How old are you? (Optional) 


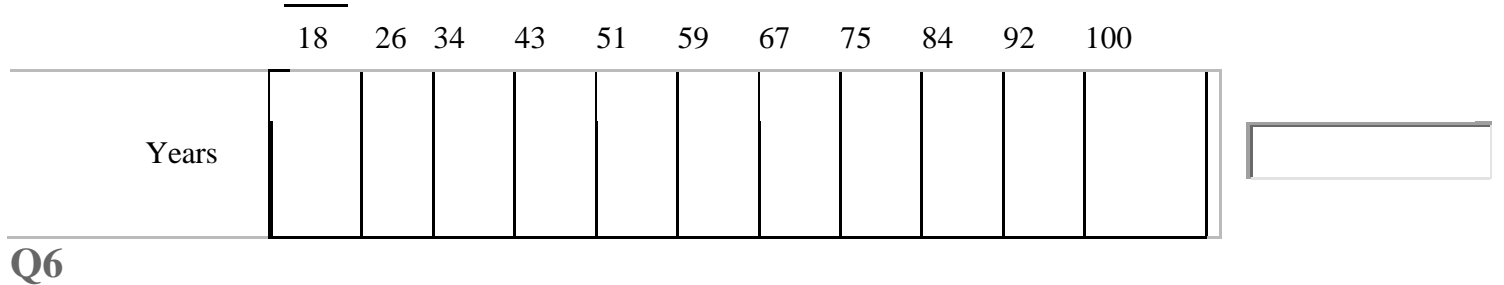

What race/ethnicity do you most closely associate with? (Optional)

Q7

\section{Display This Question:}

What gender does the executive director identify as? (Optional)

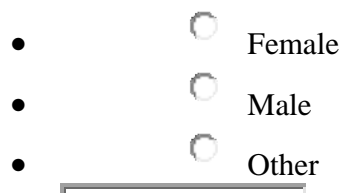

Q8

Display This Question:

What age is the executive director? (Optional)(Slide bar)

Q9

Display This Question:

What is the identified race/ethnicity of the executive director? (Optional)

\section{Q10}

Does your organization have national affiliation? (Optional)

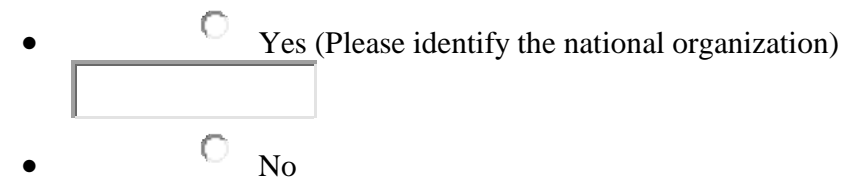

\section{Q11}

What geographic area does your organization serve?

- San Diego County 
- $\quad$ San Diego County and other areas

- $\quad$ Not in San Diego County

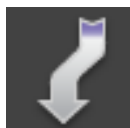

\section{Is , Then Skip To Skip Logic}

Q12

What were the total expenses for the most recent complete fiscal year? (Optional)

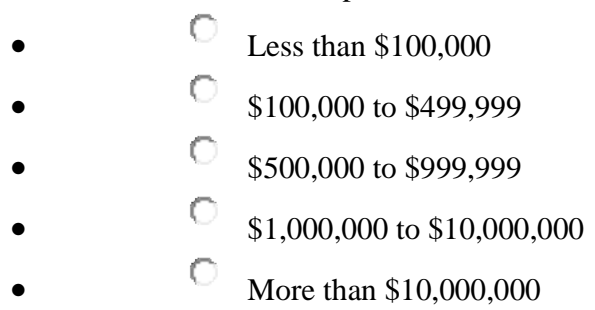

\section{Q13}

How many people are employed by the organization today?

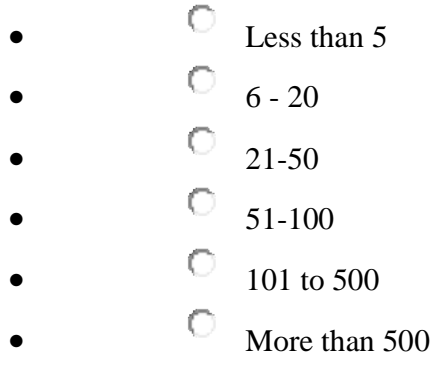

\section{Q14}

Does your organization have membership in addition to the members of the board directors?

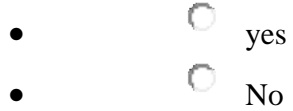


Do people who receive services from your organization participate in the following decision-making activities, in support of your organization? (Please check all that apply.)

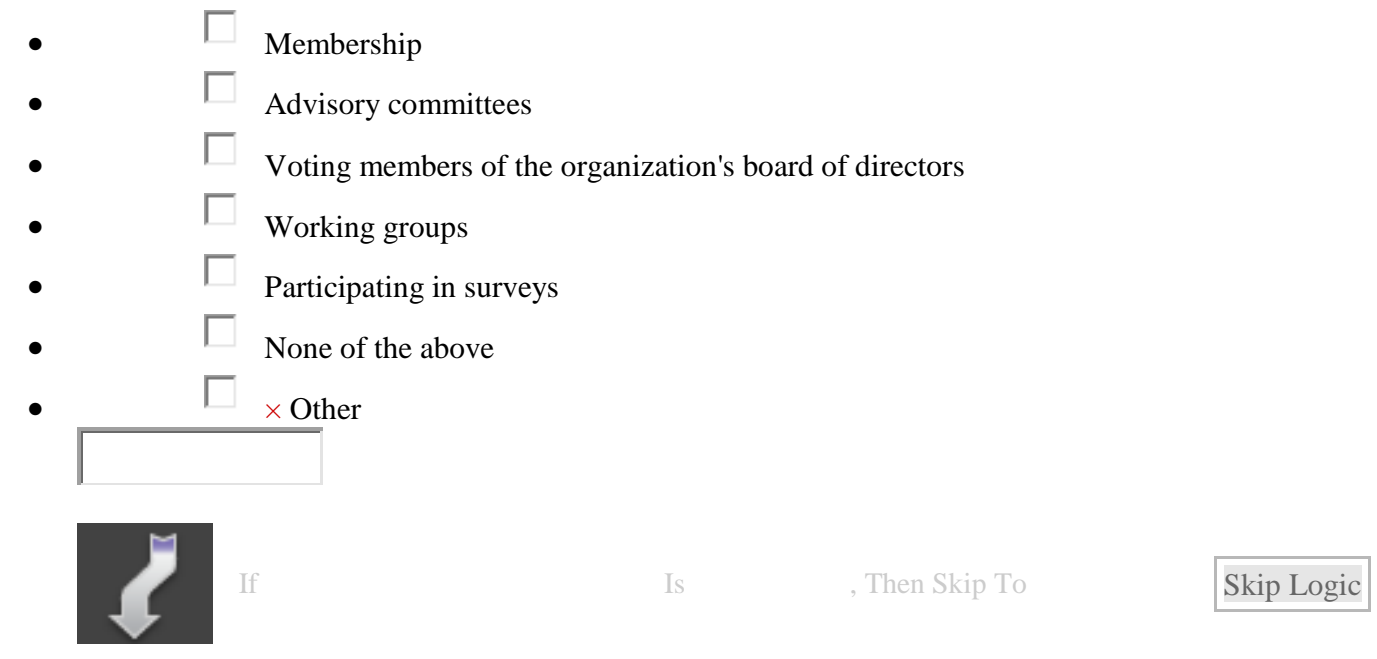

Q16

How many board members are on your Board today?

Q17

How many regularly scheduled full board meetings are there each year? (slide bar)

\section{Q18}

Number of recipients/client who are voting board members? (slide bar)

\section{Q19}

Is your organization required to have a client as a board member?

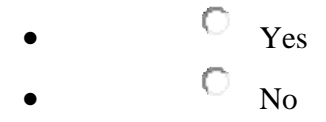

Please identify why your organization is required to have clients participating on the organization's board of directors. (Please check all that apply.)

\footnotetext{
- $\quad \Gamma$ Government agency requirement

- $\quad \Gamma$ Private funder requirement

- $\quad$ It is part of the organization's charter.
} 
If your organization is randomly selected to participate in the second phase of this research, may I contact you to arrange for distribution of a survey to your board members and to schedule a time to review the board meeting minutes for the most recent 12 months?

$\begin{array}{lll}- & \text { Yes } \\ \text { - } & \text { No }\end{array}$

If No Is Selected, Then Skip To End of Survey Skip Logic

Q22

Please provide your name and contact information.

Q23

What is the best way to contact you and when is the best time? 
APPENDIX B

Phase II Survey - Email Invitation 


\section{Phase II Survey - Email Invitation}

Dear (person's name),

Again, thank you for agreeing to participate in the second phase of my research.

I am ready to begin the next phase. This portion of my research involves reviewing your board meeting notes/minutes for the most recent 12 months of board meetings. Please let me know the most convenient way for me to review the notes. Email would be fine if they are in electronic format and you are comfortable emailing them. The notes will remain confidential and they will be protected in the same manner that the survey results are protected. Or, if you wish, I can come to your office if it is more convenient for you. I will not remove the notes and my review should take no more than 90 minutes and I will need only a small area.

The last part of this phase is asking your board members to complete a survey. The survey is in electronic format and should not take more than $\mathbf{3 0}$ minutes. I have attached a survey link. I will be able to provide you with the results of the survey in aggregate with any identifying information removed to protect the identity of your board members. Board members are encouraged to seek help if needed. I can also provide the survey in hard copy format.

Below is suggested language you might send to your board members.

We have been asked to participate in a research study being conducted by Elaine Lewis, a doctoral candidate at the University of San Diego. She is conducting research on client participation in the decision-making process of nonprofit human services organizations in San Diego County. The San Diego County Registry of Deaf Interpreters has been selected to participate in this research. All survey participants will remain anonymous and all individual survey responses will remain confidential. The information you provide will be extremely valuable to this research.

Below is a link to the survey:

Board Member Survey

When this link is sent via email, your board members will be able to access the survey either by clicking on the link or by right clicking while holding the control key down.

Again, thank you! Please feel free to contact me at any time.

Respectfully,

Elaine Lewis

University of San Diego

School of Leadership \& Education Sciences

Phone: 619-971-2801 


\section{APPENDIX C}

Phase II survey 


\section{Phase II survey}

Participatory Governance: A Mixed Methods Examination of San Diego County Nonprofit Human services Organizations

\section{Purpose of the research study}

Elaine Lewis is a doctoral candidate in the School of Leadership and Education Science at the University of San Diego. You are invited to participate in a research study she is conducting. The purpose of this research study is: To gain a better understanding of the experiences of board members serving on a board with both clients and non-clients.

\section{What you will be asked to do}

If you decide to participate in this study, you will be asked to complete an on-line survey with 31 questions which are either multiple choice or short answer.

Your participation in this study will take a total of __ $30 \_$minutes.

Should you become fatigued or tired while working with the survey you can stop and return at any time and as many times as you without losing any of your information. No information will be collected until you click the submit button.

If you want assistance completing the survey, please ask a trusted person to help you.

\section{Foreseeable risks or discomforts}

Sometimes when people are asked to think about their feelings, they feel sad or anxious. If you would like to talk to someone about your feelings at any time, you can call toll-free, 24 hours a day:

\section{San Diego Mental Health Hotline at 1-800-479-3339 TTY 619-641-6992}

\section{Benefits}

While there may be no direct benefit to you from participating in this study, the indirect benefit of participating will be knowing that you helped researchers better understand participatory governance in nonprofit organizations.

\section{Confidentiality}

Any information provided and/or identifying records will remain confidential and kept in a locked file and/or password-protected computer file in the researcher's office for a minimum of five years. All data collected from you will be coded with a number or pseudonym (fake name). Your real name will not be used. The results of this research project may be made public and information quoted in professional journals and meetings, but information from this study will only be in aggregate.

\section{Compensation}

You will receive no compensation for your participation in the study.

\section{Voluntary Nature of this Research}

Participation in this study is entirely voluntary. You do not have to do this, and you can choose to not answer any question or quit at any time. Deciding not to participate or not answering any of the questions will have no effect on any benefits you're currently receiving from the nonprofit organization, like your health care, or your employment or evaluations. You can withdraw from this study at any time without penalty. 


\section{Contact Information}

If you have any questions about this research or you would like a copy of the survey results, you may contact either:

1) Elaine Lewis

Email: elaine.lewis@sandiego.edu

Phone: 619-971-2801

2) Dr. Robert Donmoyer

Email: donmoyer@sandiego.edu

Phone: (619) 260-7445

I have read and understand this form, and consent to the research it describes to me. I may print a copy of this consent form for my records.

Please check one:

If No Is Selected, Then Skip To End of Survey Skip Logic

Q2

Are you a voting member of the Board of Directors of __(Name of the organizations)

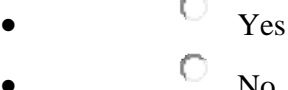

\section{If No Is Selected, Then Skip To End of Survey Skip Logic}

Q3

Do you receive services from (Name of the organization) ?<smiles></smiles>

Q4

Your age? (slide Bar) (Optional) 
Q5

The gender you most closely identify with? (Optional)

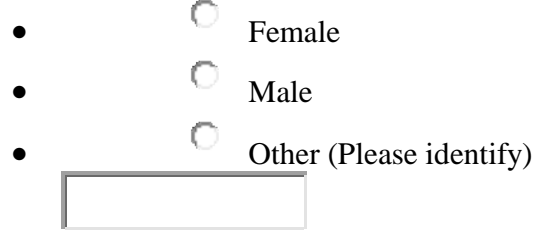

Q6

How long have you been a voting member of the board of directors?

Q7

How many meetings have you attended in the most recent 12 months? (slide bar)

Q8

Have you held any officer positions with this board? (Please select all positions held.)

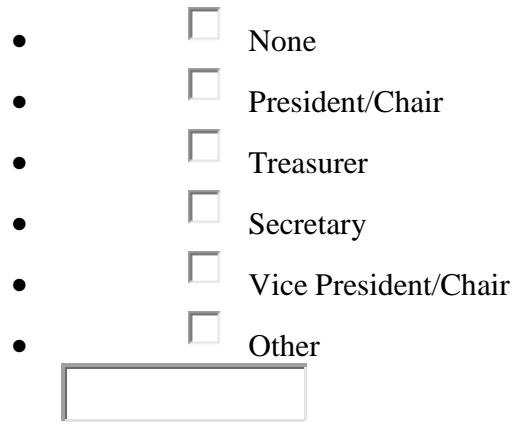

Q9

What board committees, if any, have you served on? (Select all committees served on.)

$\begin{array}{lll}\text { - } & \square \text { Have not served on a committee } \\ \text { - } & \square \text { Finance } \\ \text { - } & \square \text { Personnel } \\ \text { - } & \square \text { Audit } \\ \text { - } & \square \text { Legislative } \\ \text { - } & \square \text { Community Relations } \\ \text { - } & \square \text { Program } \\ \text { - } & \square \text { Volunteers }\end{array}$




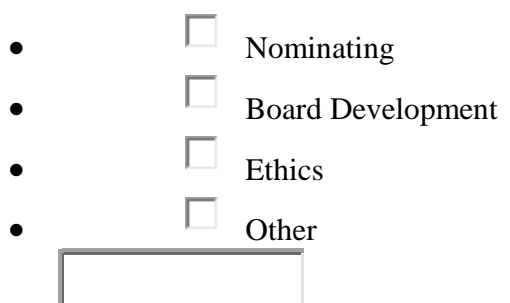

Q10

Have you chaired any committees?

- $\bigcirc$ Yes

- $\mathrm{No}$

Q11

What board committees have you chaired? (Select all committees chaired)

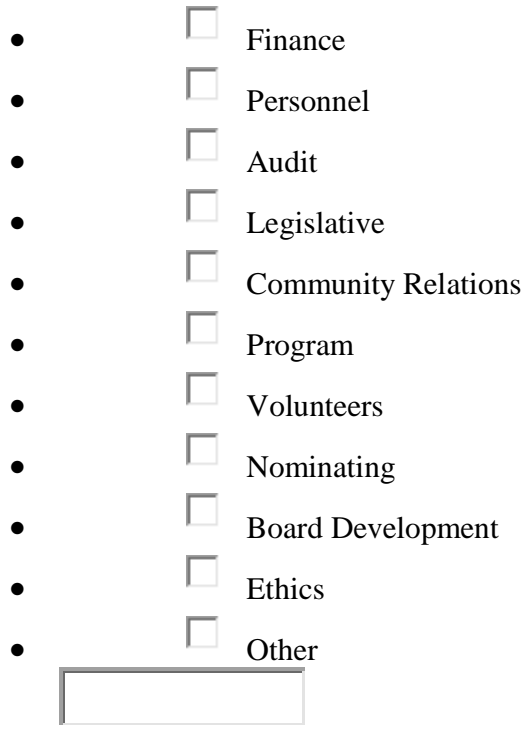

Q12

Does the board of directors have activities or functions in addition to the regular meetings?

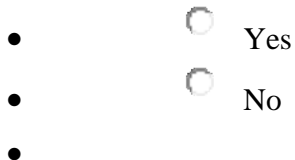




\section{If No Is Selected, Then Skip To Do you receive compensation for expen... Skip Logic}

Q13

Have you attended additional activities or functions?

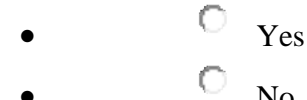

If No Is Selected, Then Skip To Do you receive compensation for expen... Skip Logic

\section{Q14}

Which additional events have you attended? (Select all activities)

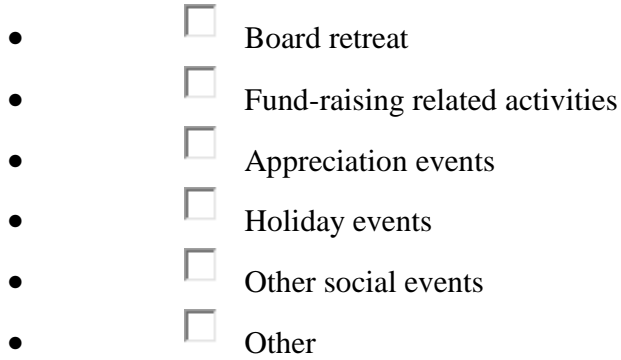

\section{Q15}

Do you receive compensation for expenses incurred by you as part of your board duties?

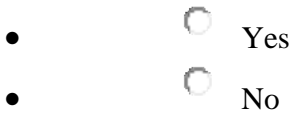

\section{Q16}

How did you become a board member e.g. invited, did you inquire, etc?

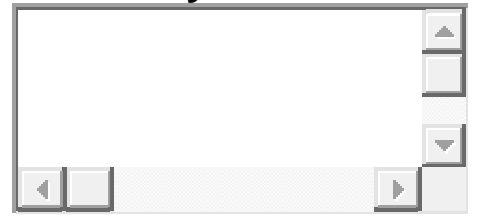




\section{Q17}

Do you have a chance to review the board material before board meetings? (Please feel free to provide additional information.)

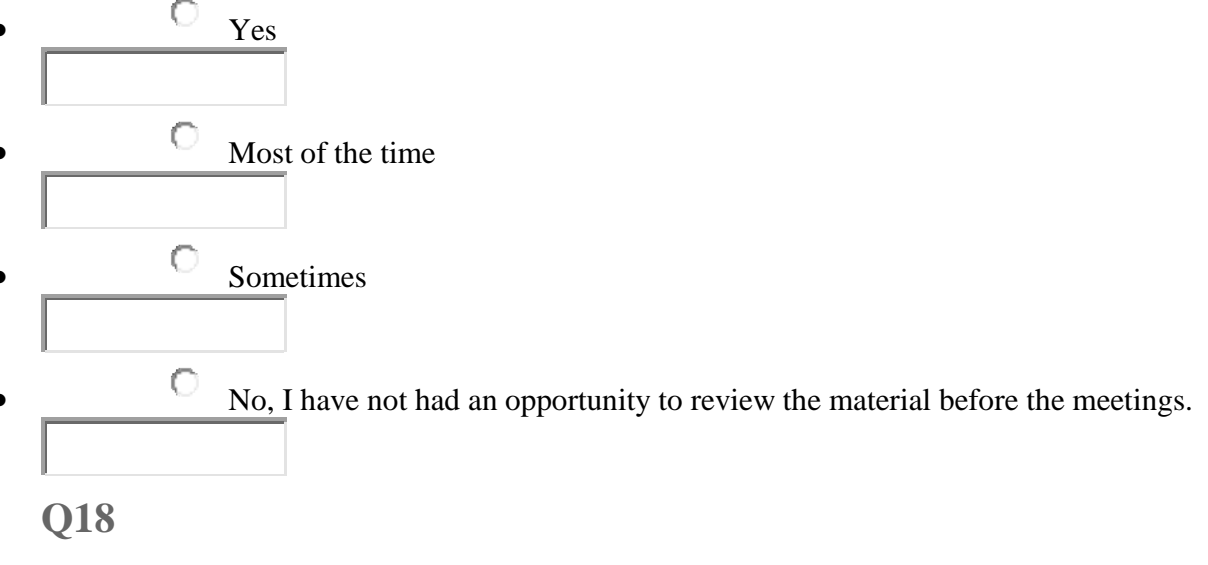

Do you feel you have enough information when you vote on a motion? (Please feel free to provide additional information.)

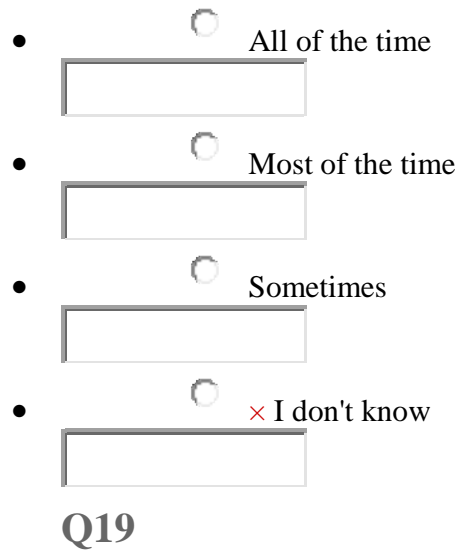

Do you feel like you are a part of the board? (Please feel free to provide additional information.)

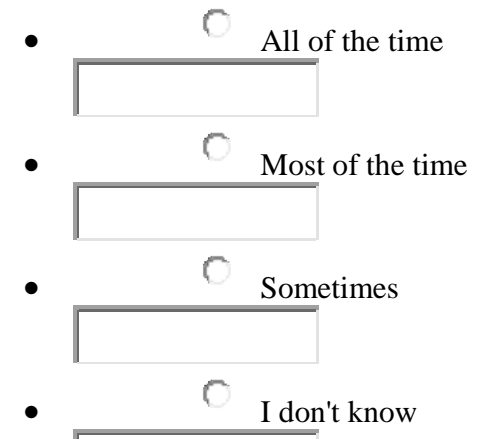


Q20

Do you feel respected as a board member? (Please feel free to provide additional information.)

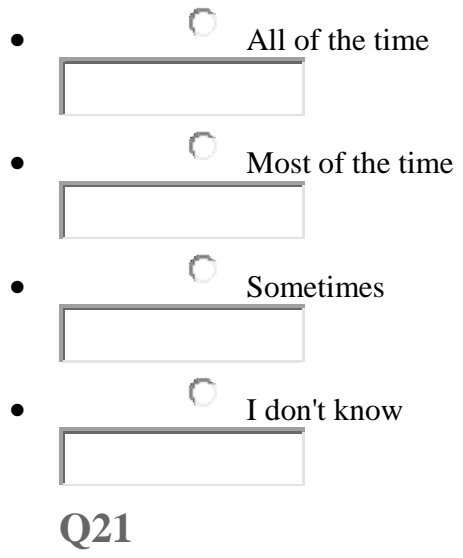

Do you feel other board members value your participation on the board? (Please feel free to provide additional information.)

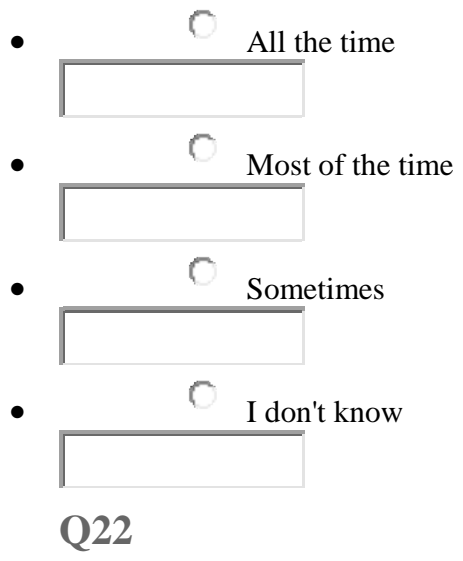

Do you feel welcome at board meetings? (Please feel free to add a comment.)

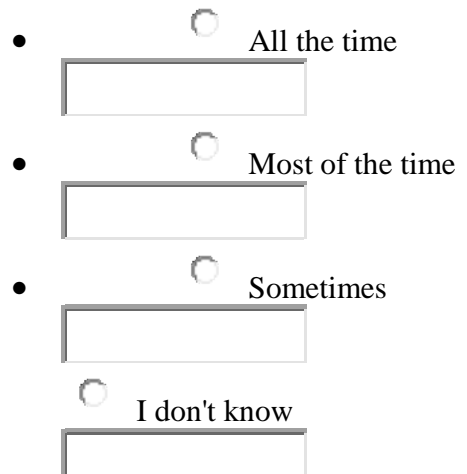




\section{Q23}

Do you feel you are fully participating on the board? (Please feel free to add a comment.)

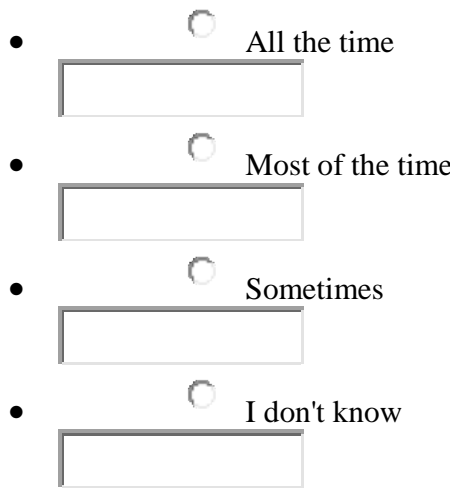

\section{Q24}

Do you volunteer for other activities associated with this organization, outside of the board meetings? (Please feel free to add a comment.)

$\bullet$

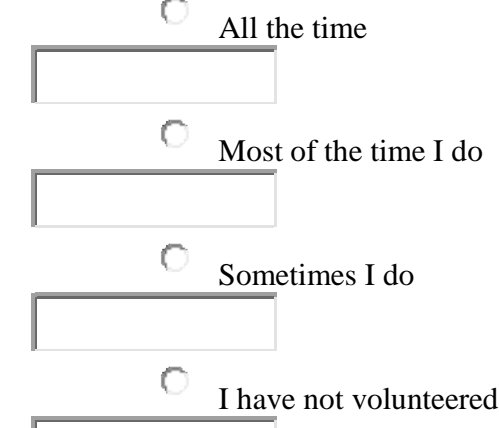

\section{Q25}

Do you feel you are making a contribution? (Please feel free to add a comment.)

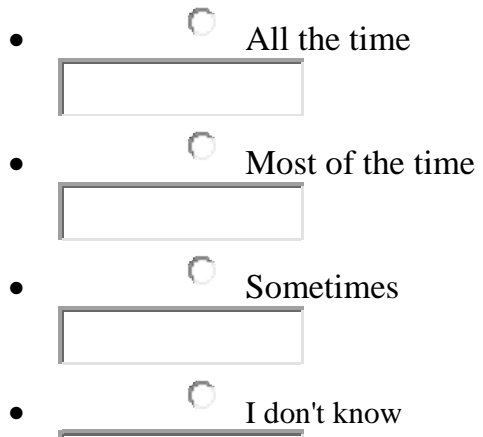


Q26

Do you feel other board members make a valuable contribution to the board? (Please feel free to add a comment.)

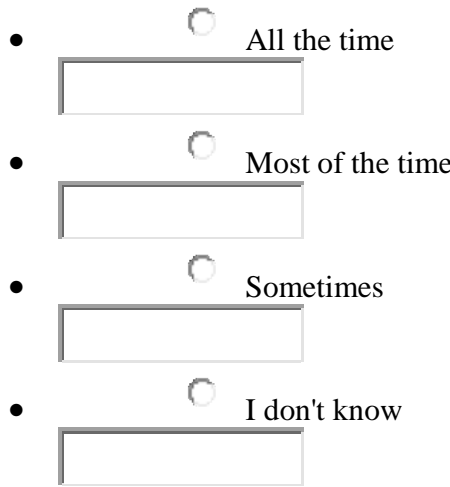

Q27

Would you like to see more people who receive services participating on the board? (Please feel free to add a comment.)

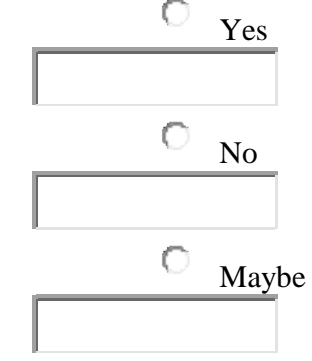

Q28

Do you feel your service on the board has been valuable to you? (Please feel free to add a comment.)

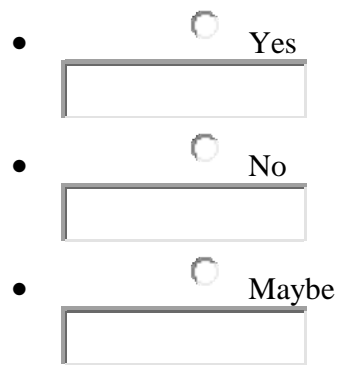




\section{Q29}

Do you feel you have been able to contribute to overall agency effectiveness?

(Please feel free to add a comment.)

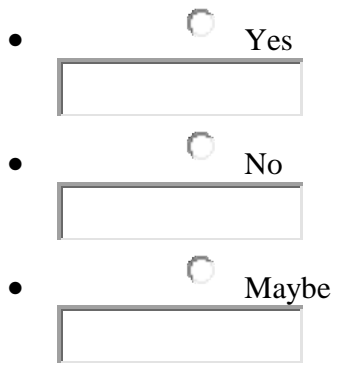

\section{Q30}

Do you feel your participation on the board has made a difference for the people served by the organization? (Please feel free to add a comment.)

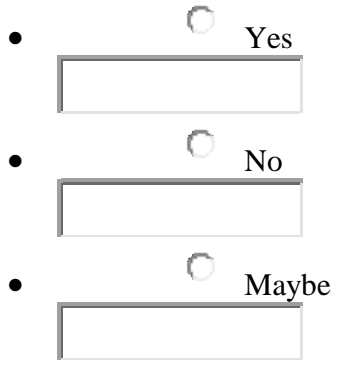

Q31

Would you serve on the board again? (Please feel free to add a comment.)

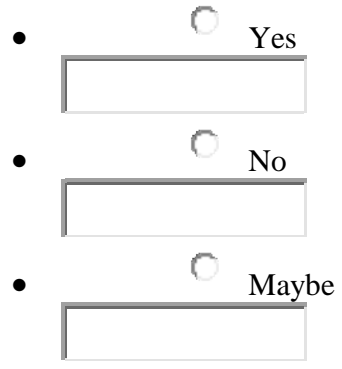

Q32

$\Gamma$

Is there anything you would like to see changed, that might make your experience as a board member more meaningful? 


\section{APPENDIX D}

Telephone survey questions and response totals 


\section{Telephone survey questions and response totals}

A total of 47 organizations responded to the telephone survey questions.

\begin{tabular}{|l|l|l|l|l|l|}
\hline $\begin{array}{l}\text { Does your } \\
\text { organization } \\
\text { have } \\
\text { membership? }\end{array}$ & $\begin{array}{l}\text { Are any of } \\
\text { the clients } \\
\text { members? }\end{array}$ & $\begin{array}{l}\text { Do any of } \\
\text { the clients } \\
\text { serve on an } \\
\text { Advisory } \\
\text { committee? }\end{array}$ & $\begin{array}{l}\text { Do any of } \\
\text { the clients } \\
\text { sit on the } \\
\text { board of } \\
\text { directors? }\end{array}$ & $\begin{array}{l}\text { Do any } \\
\text { clients } \\
\text { participate } \\
\text { in working } \\
\text { groups? }\end{array}$ & \begin{tabular}{l}
$\begin{array}{l}\text { Does your } \\
\text { agency send } \\
\text { surveys out } \\
\text { to the } \\
\text { clients? }\end{array}$ \\
\hline \multicolumn{6}{|c|}{}
\end{tabular} \\
\hline 9 & 7 & 10 & 11 & 6 & 17 \\
\hline
\end{tabular}




\section{APPENDIX E}

Nonresponse Bias 


\section{Nonresponse Bias}

Testing for nonresponse bias using Chi Square. Degrees of freedom $=9$ at the 0.01 level

Nonresponse Bias calculated the Chi Squared Critical Value Distribution Table

NTEE-CC categories for the population of human services organizations and the NTEE-CC categories for the sample

\begin{tabular}{|c|c|c|c|c|c|c|c|c|c|c|c|c|c|}
\hline & & 1 & 2 & 3 & 4 & 5 & 6 & 7 & 8 & 9 & 10 & & \\
\hline Expected & Populatior & 8 & 14 & 75 & 30 & 33 & 28 & 18 & 35 & 77 & 11 & 329 & \\
\hline Pop \% & & 0.02 & 0.04 & 0.23 & 0.09 & 0.10 & 0.09 & 0.05 & 0.11 & 0.23 & 0.03 & & \\
\hline Observed & Responder & 2.00 & 1.00 & 6.00 & 4.00 & 10.00 & 6.00 & 4.00 & 9.00 & 17.00 & 2.00 & 61 & \\
\hline \multirow[t]{4}{*}{ Expected } & & 1.48 & 2.60 & 13.91 & 5.56 & 6.12 & 5.19 & 3.34 & 6.49 & 14.28 & 2.04 & & $E=p o p \% * 61$ \\
\hline & o-e & -0.52 & 1.60 & 7.91 & 1.56 & -3.88 & -0.81 & -0.66 & -2.51 & -2.72 & 0.04 & & \\
\hline & o-e square & 0.27 & 2.55 & 62.50 & 2.44 & 15.07 & 0.65 & 0.44 & 6.30 & 7.42 & 0.00 & & \\
\hline & squared/e & 0.18 & 0.98 & 4.49 & 0.44 & 2.46 & 0.13 & 0.13 & 0.97 & 0.52 & 0.00 & 10.31 & Chi Squared \\
\hline
\end{tabular}

Percentage Points of the Chi-Square Distribution

\begin{tabular}{|c|c|c|c|c|c|c|c|c|c|}
\hline \multirow{2}{*}{$\begin{array}{l}\text { Degrees of } \\
\text { Freedom }\end{array}$} & \multicolumn{9}{|c|}{ Probability of a larger value of $x^{2}$} \\
\hline & 0.99 & 0.95 & 0.90 & 0.75 & 0.50 & 0.25 & 0.10 & 0.05 & 0.01 \\
\hline 1 & 0.000 & 0.004 & 0.016 & 0.102 & 0.455 & 1.32 & 2.71 & 3.84 & 6.63 \\
\hline 2 & 0.020 & 0.103 & 0.211 & 0.575 & 1.386 & 2.77 & 4.61 & 5.99 & 9.21 \\
\hline 3 & 0.115 & 0.352 & 0.584 & 1.212 & 2.366 & 4.11 & 6.25 & 7.81 & 11.34 \\
\hline 4 & 0.297 & 0.711 & 1.064 & 1.923 & 3.357 & 5.39 & 7.78 & 9.49 & 13.28 \\
\hline 5 & 0.554 & 1.145 & 1.610 & 2.675 & 4.351 & 6.63 & 9.24 & 11.07 & 15.09 \\
\hline 6 & 0.872 & 1.635 & 2.204 & 3.455 & 5.348 & 7.84 & 10.64 & 12.59 & 16.81 \\
\hline 7 & 1.239 & 2.167 & 2.833 & 4.255 & 6.346 & 9.04 & 12.02 & 14.07 & 18.48 \\
\hline 8 & 1.647 & 2.733 & 3.490 & 5.071 & 7.344 & 10.22 & 13.36 & 15.51 & 20.09 \\
\hline 9 & 2.088 & 3.325 & 4.168 & 5.899 & 8.343 & 11.39 & 14.68 & 16.92 & 21.67 \\
\hline 10 & 2.558 & 3.940 & 4.865 & 6.737 & 9.342 & 12.55 & 15.99 & 18.31 & 23.21 \\
\hline 11 & 3.053 & 4.575 & 5.578 & 7.584 & 10.341 & 13.70 & 17.28 & 19.68 & 24.72 \\
\hline 12 & 3.571 & 5.226 & 6.304 & 8.438 & 11.340 & 14.85 & 18.55 & 21.03 & 26.22 \\
\hline 13 & 4.107 & 5.892 & 7.042 & 9.299 & 12.340 & 15.98 & 19.81 & 22.36 & 27.69 \\
\hline 14 & 4.660 & 6.571 & 7.790 & 10.165 & 13.339 & 17.12 & 21.06 & 23.68 & 29.14 \\
\hline 15 & 5.229 & 7.261 & 8.547 & 11.037 & 14.339 & 18.25 & 22.31 & 25.00 & 30.58 \\
\hline
\end{tabular}




\section{APPENDIX F}

Online Survey Responses to Demographic Questions 
Online Survey Responses to Demographic Questions

\begin{tabular}{|c|c|c|c|c|c|c|}
\hline $\begin{array}{l}\text { Online Survey } \\
\text { Responses to } \\
\text { Demographic } \\
\text { Questions }\end{array}$ & & & & & & \\
\hline \multirow[t]{2}{*}{$\begin{array}{l}\text { Person } \\
\text { Completing the } \\
\text { survey }\end{array}$} & $\mathrm{CEO}$ & $\begin{array}{l}\text { Board } \\
\text { member }\end{array}$ & Admin. & Man. & & Missing \\
\hline & 15 & 4 & 3 & 3 & & 0 \\
\hline \multirow[t]{2}{*}{ CEO Race } & White & Hispanic & Spanish & & & \\
\hline & 18 & 1 & 1 & & & 5 \\
\hline \multirow[t]{2}{*}{ CEO Gender } & Female & Male & & & & \\
\hline & 9 & 1 & & & & 15 \\
\hline \multirow[t]{2}{*}{$\begin{array}{l}\text { National } \\
\text { Affiliation }\end{array}$} & Yes & No & & & & \\
\hline & 6 & 19 & & & & 0 \\
\hline \multirow[t]{2}{*}{ Annual Expenses } & $<\$ 100,000$ & $\begin{array}{l}\$ 100 \mathrm{k}- \\
\$ 499 \mathrm{k}\end{array}$ & $\begin{array}{l}\$ 500 \mathrm{k}- \\
\$ 999 \mathrm{k}\end{array}$ & $\begin{array}{l}\$ 1 \text { mil- } \\
\$ 10 \\
\text { mil } \\
\end{array}$ & $\begin{array}{c}\$ \$ 10 \mathrm{mi} \\
1\end{array}$ & \\
\hline & 6 & 6 & 4 & 4 & 3 & 2 \\
\hline \multirow[t]{2}{*}{$\begin{array}{l}\text { Number of } \\
\text { Annual Board } \\
\text { Meetings } \\
\end{array}$} & $1-4$ & $6 \& 7$ & 10 & 11 & 12 & \\
\hline & 6 & 3 & 3 & 4 & 4 & 5 \\
\hline \multirow{2}{*}{$\begin{array}{c}\text { Number of Board } \\
\text { members }\end{array}$} & Range & Average & Mode & & & \multirow{2}{*}{5} \\
\hline & 3 to 17 & 8.65 & 9 & & & \\
\hline
\end{tabular}




\section{APPENDIX G}

ORG-C Board Meeting Review Data 


\section{ORG-C Board Meeting Review Data}

\begin{tabular}{|c|c|c|c|c|}
\hline ORG-C & Average & Range & $\begin{array}{c}\text { Client 1 } \\
\text { Participation }\end{array}$ & $\begin{array}{c}\text { Client 2 } \\
\text { Participation }\end{array}$ \\
\hline Meetings attended & 8.4 meetings & $1-11$ meetings & 9 meetings & 3 meetings \\
\hline $\begin{array}{c}\text { Motions made } \\
\text { during } 11 \text { board } \\
\text { meetings }\end{array}$ & $\begin{array}{c}3 \text { motions per board } \\
\text { member }\end{array}$ & $0-16$ motions & 2 motion made & 1 motion made \\
\hline $\begin{array}{c}\text { Seconds made } \\
\text { during } 11 \text { board } \\
\text { meetings }\end{array}$ & $\begin{array}{c}3 \text { seconds per board } \\
\text { member }\end{array}$ & 0 -15 seconds & 3 seconds made & 0 seconds made \\
\hline $\begin{array}{c}\text { Committee } \\
\text { participation }\end{array}$ & $\begin{array}{c}6 \text { committees per board } \\
\text { member }\end{array}$ & 0 -19 committees & 5 committees & committee \\
\hline $\begin{array}{c}\text { Held an officers } \\
\text { position }\end{array}$ & $\begin{array}{c}5 \text { board members held } \\
\text { an officers position }\end{array}$ & $\begin{array}{c}9 \text { board members did } \\
\text { not hold an officers } \\
\text { position }\end{array}$ & $\begin{array}{c}\text { Held } 1 \text { officers } \\
\text { position }\end{array}$ & $\begin{array}{c}\text { Did not hold an } \\
\text { officers position }\end{array}$ \\
\hline Board Chair & 2 people held the Chair & $\begin{array}{c}11 \text { board members did } \\
\text { not hold the Chair } \\
\text { position }\end{array}$ & Did not & Did not \\
Chair & Chair \\
\hline
\end{tabular}




\section{APPENDIX H}

National Taxonomy of Exempt Entities-Core Codes (NTEE-CC) classification system 


\section{National Taxonomy of Exempt Entities-Core Codes (NTEE-CC) classification system}

\section{NATIONAL TAXONOMY OF EXEMPT ENTITIES - CORE CODES (NTEE-CC) CLASSIFICATION SYSTEM (rev. May 2005)}

\section{ARTS, CULTURE \& HUMANITIES}

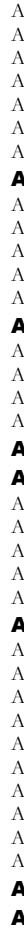

Alliances \& Advocacy

Management \& Technical Assistance

Professional Societies \& Associations

Research Institutes \& Public Policy Analysis

Single Organization Support

Fund Raising \& Fund Distribution

Support NEC

Arts \& Culture

Cultural \& Ethnic Awareness

Folk Arts

Arts Education

Arts \& Humanities Councils \& Agencies

Community Celebrations

Media \& Communications

Film \& Video

Television

Printing \& Publishing

Radio

Visual Arts

Museums

Art Museums

Children's Museu

History Museum

\& Natural Science Museums

Science \& Technology Museums

Performing Arts

Performing Arts Centers

Dance

Ballet

Theate

Theate

Symphony Orchestras

Symph

Opera

Singing \& Choral Groups

Bands \& Ensembles

Performing Arts Schools

Humanities

A80 Historical Organizations

A82 Historical Societies \& Historic Preservation

Commemorative Events

Arts Services

A99 Arts, Culture \& Humanities NEC

B EDUCATION

B01 Alliances \& Advocacy

Management \& Technical Assistance

Professional Societies \& Association

Research Institutes \& Public Policy Analysis

Single Organization Support

Fund Raising \& Fund Distribution

Support NEC

20 Elementary \& Secondary Schools

B21 Preschools

Primary \& Elementary Schools

Secondary \& High Schools

Special Education

Charter Schools

Vocational \& Technical Schools

Higher Education

Two-Year Colleges

Undergraduate Colleges

Universities

50 Graduate \& Professional Schools

B60 Adult Education

B70 Libraries

B80 Student Services

S82 Scholarships \& Student Financial Aid

Student Sororities \& Fraternitie

B84 Alumni Associations

B90 Educational Services

B92 Remedial Reading \& Encouragement

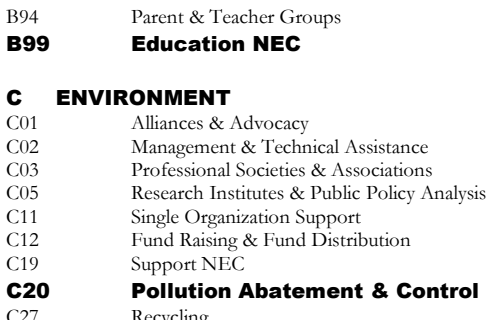

C27

C30 Natural Resources Conservation \& Protection

C32 Water Resources, Wetlands Conservation \& Management
C34

C34 Land Resources Conservation

C35 Energy Resources Conservation \& Development
C36 Forest Conservation

C40 Botanical, Horticultural \& Landscape Services

C41 Botanical Gardens \& Arboreta

C42 Garden Clubs

C50 Environmental Beautification

C60 Environmental Education

C99 Environment NEC

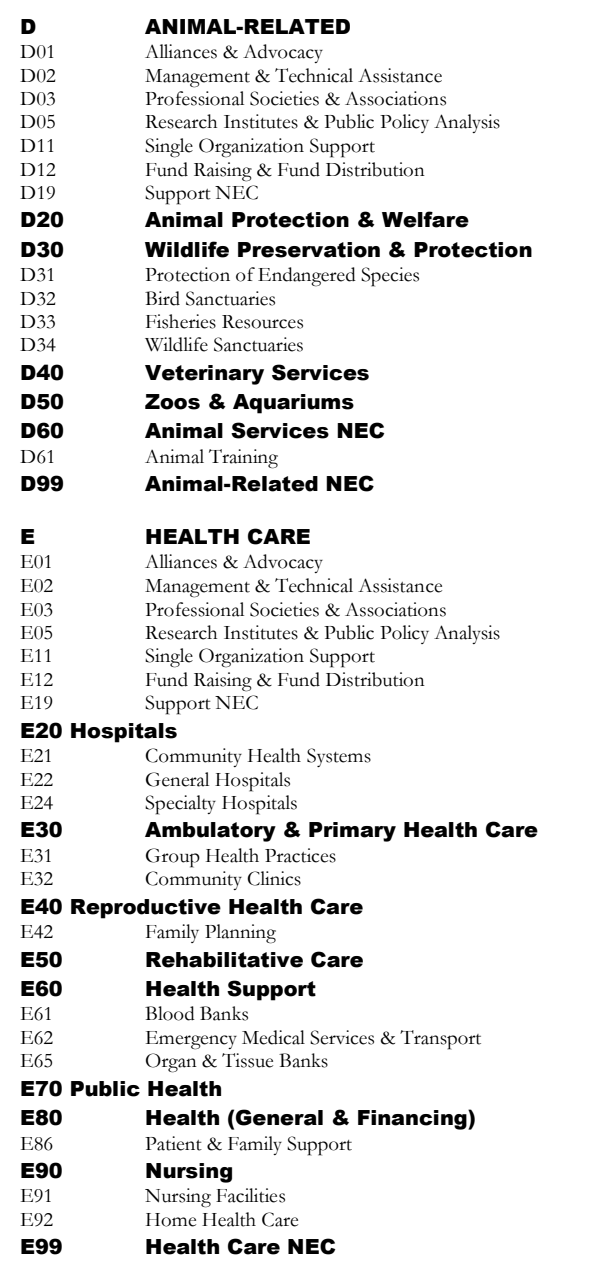




\section{MENTAL HEALTH \& CRISIS INTERVENTION}

Alliances \& Advocac

Management \& Technical Assistance

Professional Societies \& Association

Research Institutes \& Public Policy Analysis

Single Organization Support

Fund Raising \& Fund Distribution Support NEC

0 Substance Abuse Dependency, Prevention \& Treatment

Substance Abuse Prevention

Substance Abuse Treatment

Mental Health Treatment

Psychiatric Hospitals

Community Mental Health Centers

Residential Mental Health Treatment

Hot Lines \& Crisis Intervention

Sexual Assault Services

Addictive Disorders NEC

Smoking Addiction

Eating Disorders \& Addictions

Gambling Addiction

Counseling

Mental Health Disorders

Mental Health Associations

99 Mental Health \& Crisis Intervention NEC

G80

\section{H MEDICAL RESEARCH}

H01 Alliances \& Advocacy

H02 Management \& Technical Assistance

Professional Societies \& Association

Research Institutes \& Public Policy Analysis

Single Organization Support

Fund Raising \& Fund Distribution

Support NEC

20 Birth Defects \& Genetic Diseases Research

H25 Down Syndrome Research

H30 Cancer Research

H32 Breast Cancer Research

H40 Diseases of Specific Organ Research

Eye Diseases, Blindness \& Vision Impairments Research

Ear \& Throat Diseases Research

Ear \& Throat Diseases Research
Heart \& Circulatory System Diseases \& Disorders Research

Kidney Diseases Research

Lung Diseases Research

Brain Disorders Research

50 Nerve, Muscle \& Bone Diseases Research

$\mathrm{H} 51$

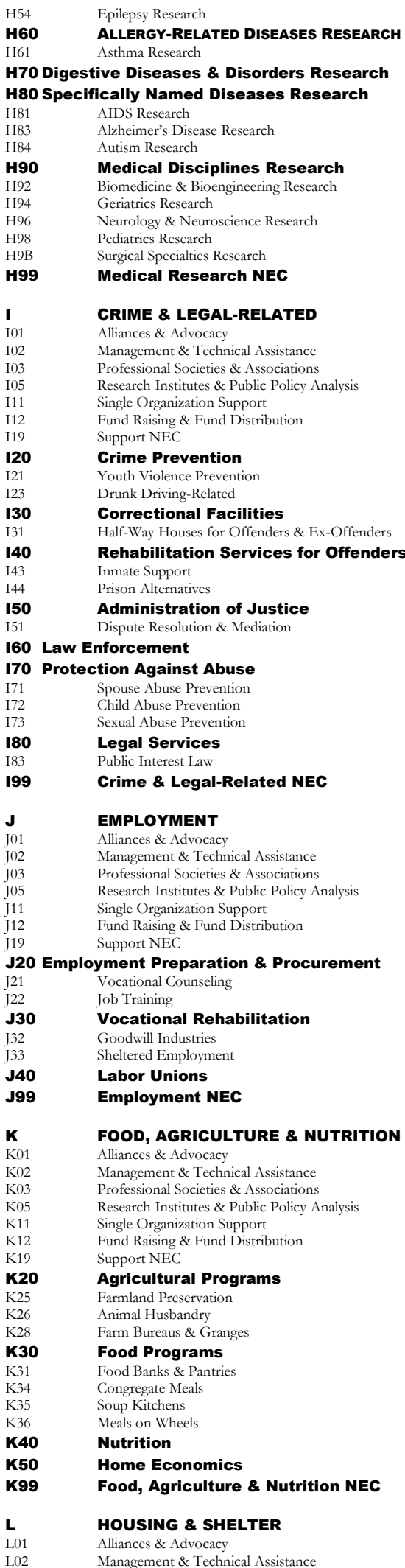


Professional Societies \& Associations

Research Institutes \& Public Policy Analysis

Single Organization Support

Fund Raising \& Fund Distribution

Support NEC

Housing Development, Construction \& Management

Low-Income \& Subsidized Rental Housing

Senior Citizens' Housing \& Retirement Communities

Independent Housing for People with Disabilities

Housing Rehabilitation

Housing Search Assistance

Temporary Housing

Homeless Shelter

Homeowners \& Tenants Associations

Housing Support

Home Improvement \& Repairs

Housing Expense Reduction Support

Housing \& Shelter NEC

\section{PUBLIC SAFETY, DISASTER PREPAREDNESS \& RELIEF} Alliances \& Advocac

Management \& Technical Assistance

Professional Societies \& Associntion

Research Institutes \& Public Policy Analysis

Single Organization Support

Fund Raising \& Fund Distribution

Support NEC

20 Disaster Preparedness \& Relief Services

M23 Search \& Rescue Squads

M24 Fire Prevention

M40 Safety Education

M41 First Aid

Automotive Safety

M60 Public Safety Benevolent Associations

M99 Public Safety, Disaster Preparedness \& Relief NEC

Management \& Technical Assistance

Professional Societies \& Association

Research Institutes \& Public Policy Analysis

Single Organization Support

Fund Raising \& Fund Distribution

Support NEC

Camps

N30 Physical Fitness \& Community Recreational Facilities

N31 Community Recreational Centers

N32 Parks \& Playgrounds

N40 Sports Associations \& Training Facilities

N50 Recreational Clubs

N52 Fairs

N60 Amateur Sports

N61 Fishing \& Hunting

N62 Basketball

Baseball \& Softball

S64 Soccer

N66 Racquet Sports

N67 Swimming \& Other Water Recreation

Winter Sports

Equestrian

Golf

N70 Amateur Sports Competitions

$\begin{array}{ll}\text { N70 } & \text { Amateur } \\ \text { N71 } & \text { Olympics }\end{array}$

N72 Special Olympics

N80 Professional Athletic Leagues

N99 Recreation \& Sports NEC

○

YOUTH DEVELOP
Alliances \& Advocacy

Management \& Technical Assistance

Professional Societies \& Association

Research Institutes \& Public Policy Analysis

Single Organization Support

Fund Raising \& Fund Distribution

Support NEC

Youth Centers \& Clubs

Boys Clubs

Girls Clubs

Boys \& Girls Clubs

Adult \& Child Matching Programs

Big Brothers \& Big Sisters

O40 Scouting Organizations

O41 Boy Scouts of America
Girl Scouts of the U.S.A

Camp Fire

Youth Development Programs

Youth Community Service Clubs

Youth Development - Agricultural

Youth Development - Business

Youth Development - Citizenship

Youth Development - Religious Leadership

Youth Development NEC

\section{HUMAN SERVICES}

Alliances \& Advocacy

Management \& Technical Assistance

Professional Societies \& Associations

Research Institutes \& Public Policy Analysis

Single Organization Support

Fund Raising \& Fund Distribution

Support NEC

Human Services

American Red Cross

Urban League

Salvation Arm

Volunteers of America

Young Men's or Women's Associations

Neighborhood Centers

Thrift Shops

Children \& Youth Services

Adoption

Child Day Care

Family Services

Single Parent Agencies

Family Violence Shelter

In-Home Assistance

Family Services for Adolescent Parent

Family Counseling

Pregnancy Centers

Personal Social Services

Financial Counseling

ransportation Assistance

Gift Distribution

Emergency Assistance

Travelers' Aid

Victims' Services

P70 Residential Care \& Adult Day Programs

Adult Day Care

Group Homes

Hospices

Supportive Housing for Older Adults

80 Centers to Support the Independence of Specific Populations

$\begin{array}{ll}\text { P81 } & \text { Senior Centers } \\ \text { P82 } & \text { Developmentally Disabled Centers }\end{array}$

Ethnic \& Immigrant Cente

Blind \& Visually Impaired Centers

Deaf \& Hearing Impaired Centers

LGBT Centers

P99

Human Services NEC

\section{INTERNATIONAL, FOREIGN AFFAIRS \& NATIONAL SECURITY} Alliances \& Advocac

Management \& Technical Assistance

Professional Societies \& Associations

Research Institutes \& Public Policy Analysis

Single Organization Support

Fund Raising \& Fund Distribution

Support NEC

20 Promotion of International Understanding

Q21 International Cultural Exchange

International Academic Exchan

International Exchange NEC

International Development

International Agricultural Development

International Economic Development

International Relief

Democracy \& Civil Society Development

International Peace \& Security

Arms Control \& Peace

United Nations Association

National Security

Q50 International Affairs, Foreign Policy \& Globalization

Q51 International Economic \& Trade Policy

Q70 International Human Rights

Q71 International Migration \& Refugee Issues

Q99 International, Foreign Affairs \& National Security NEC 


\section{CIVIL RIGHTS, SOCIAL ACTION \& ADVOCACY}

Alliances \& Advocacy

Management \& Technical Assistance

Professional Societies \& Association

Research Institutes \& Public Policy Analysis

Single Organization Support

Fund Raising \& Fund Distribution

Fund Raising \&

Civil Rights

Minority Rights

Disabled Persons' Rights

Women's Rights

Seniors' Rights

Lesbian and Gay Right

Children's Rights

Intergroup \& Race Relations

Voter Education \& Registration

Civil Liberties

Reproductive Rights

Right to Life

Censorship, Freedom of Speech \& Press

Right to Die \& Euthanasi

R99 Civil Rights, Social Action \& Advocacy NEC

COMMUNITY IMPROVEMENT \& CAPACITY BUILDING

Alliances \& Advocacy

Management \& Technical Assistance

Professional Societies \& Association

Research Institutes \& Public Policy Analysis

Single Organization Support

Fund Raising \& Fund Distribution

Support NEC

20 Community \& Neighborhood Development

S21 Community Coalitions

22 Neighborhood \& Block Association

S30 Economic Development

$31 \quad$ Urban \& Community Economic Development

S32 Rural Economic Development

S40 Business \& Industry

S41 Chambers of Commerce \& Business Leagues

Small Business Developmen

Boards of Trade

Real Estate Associations

Nonprofit Management

Community Service Clubs

Women's Service Clubs

Men's Service Clubs

599 Community Improvement \& Capacity Building NEC

T PHILANTHROPY, VOLUNTARISM \& GRANTMAKING FOUNDATIONS

Alliances \& Advocacy

Management \& Technical Assistance

Professional Societies \& Association

Research Institutes \& Public Policy Analysis

Single Organization Support

Fund Raising \& Fund Distribution

Support NEC

Private Grantmaking Foundations

Corporate Foundations

Private Independent Foundations

Private Operating Foundations

Public Foundations

Community Foundations

Voluntarism Promotion

0 Philanthropy, Charity \& Voluntarism Promotion

Federated Giving Programs

Named Trusts NEC

T99 Philanthropy, Voluntarism \& Grantmaking Foundations NEC

SCIENCE \& TECHNOLOGY

Alliances \& Advocacy

Management \& Technical Assistance

Professional Societies \& Association

Research Institutes \& Public Policy Analysis

Single Organization Support

Fund Raising \& Fund Distribution

Support NEC

20 General Science

Marine Science \& Oceanography

U30 Physical \& Earth Sciences

U31 Astronomy

U33 Chemistry \& Chemical Engineering

U34 Mathematics

U36 Geology

U40 Engineering \& Technology

$41 \quad$ Computer Science

U50 Biological \& Life Sciences

U99 Science \& Technology NEC

$\checkmark$ SOCIAL SCIENCE

Alliances \& Advocacy

V02 Management \& Technical Assistance

Research Institutes \& Public Policy Analysis

Single Organization Suppor

Fund Raising \& Fund Distribution

Support NEC

Social Science

Anthropology \& Sociology

Economics

Behavioral Science

Political Science

Population Studies

Law \& Jurisprudence

Interdisciplinary Research

Black Studies

Women's Studies

Ethnic Studies

Utran Studies

International Studies

Gerontology

Labor Studies

V99 Social Science NEC

W PUBLIC \& SOCIETAL BENEFIT

W01 Alliances \& Advocacy

W02 Management \& Technical Assistance

Professional Societies \& Associations

Research Institutes \& Public Policy Analysi

Single Organization Support

Fund Raising \& Fund Distribution

Support NEC

Government \& Public Administration

Public Finance, Taxation \& Monetary Policy

Citizen Participation

Military \& Veterans' Organizations

Public Transportation Systems

W50Telecommunications

W60Financial Institutions

W61 Credit Unions

w70 Leadership Development

w80 Public Utilities

W90 Consumer Protection

W99Public \& Societal Benefit NEC

$\begin{array}{ll}\text { X } & \text { RELIGION-RELATED } \\ \text { X01 } & \text { Alliances \& Advocacy } \\ \text { X02 } & \text { Management \& Technical Assistance } \\ \text { X03 } & \text { Professional Societies \& Associations } \\ \text { X05 } & \text { Research Institutes \& Public Policy Analysis } \\ \text { X11 } & \text { Single Organization Support } \\ \text { X12 } & \text { Fund Raising \& Fund Distribution } \\ \text { X19 } & \text { Support NEC } \\ \text { X20 } & \text { Christianity } \\ \text { X21 } & \text { Protestant } \\ \text { X22 } & \text { Roman Catholic } \\ \text { X30 } & \text { Judaism } \\ \text { X40 } & \text { Islam } \\ \text { X50 } & \text { Buddhism } \\ \text { X70 } & \text { Hinduism } \\ \text { X80 } & \text { Religious Media \& Communications } \\ \text { X81 } & \text { Religious Film \& Video } \\ \text { X82 } & \text { Religious Television } \\ \text { X83 } & \text { Religious Printing \& Publishing } \\ \text { X84 } & \text { Religious Radio } \\ \text { X90 } & \text { Interfaith Coalitions } \\ \text { X99 } & \text { Religion-Related NEC } \\ & \\ \text { Y } & \text { MUTUAL \& MEMBERSHIP BENEFIT } \\ \text { Y01 } & \text { Alliances \& Advocacy } \\ \text { Y02 } & \text { Management \& Technical Assistance } \\ \text { Y03 } & \text { Professional Societies \& Associations } \\ \text { Y05 } & \text { Research Institutes \& Public Policy Analysis } \\ \text { Y11 } & \text { Single Organization Support } \\ & \end{array}$


Fund Raising \& Fund Distribution

Support NEC

Insurance Providers

Local Benevolent Life Insurance Associations, Mutual Irrigation \&

Telephone Companies \& Like Organizations

Mutual Insurance Companies \& Associations

Comployment Compensation

State-Sponsored Worker's Compensation Reinsurance Organizations

Pension \& Retirement Funds

Teachers Retirement Fund Associations

Employee Funded Pension Trusts

Multi-Employer Pension Plans

Fraternal Societies

Fraternal Beneficiary Societic

Domestic Fraternal Societies

Voluntary Employees Beneficiary Associations (Non-Government)

iary Associations (Government)

Cemeteries
Y99

$\mathbf{z}$

Z99 Unknown

NEC $=$ Not Elsewhere Classified

The National Taxonomy of Exempt Entities - Core Codes (NTEE-CC) is the industry-wide standard for nonprofit organizational classification.

or more information, please contact:

The National Center for Charitable Statistics @

The Center on Nonprofits and Philanthropy

The Urban Institute

Website: www.nccs.urban.or

Email: NCCS@ui.urban.or

Revised: MAY 2005 


\section{Institutional Review Board Project Action Summary}

Action Date: June 4, 2015

Note: Approval expires one year after this date.

Type: __New Full Review ___NNew Expedited Review __ Continuation Review __Exempt Review Modification

Action:__ X_Approved__ _ Approved Pending Modification _ _ Not Approved

Project Number: 2015-06-273

Researcher(s): $\quad$ Elaine Marie Lewis Doc SOLES

Dr. Robert Donmoyer Fac SOLES

Project Title: $\quad$ Participatory Governance: A Mixed Methods Examination of San Diego County Human Service Organizations

Note: We send IRB correspondence regarding student research to the faculty advisor, who bears the ultimate responsibility for the conduct of the research. We request that the faculty advisor share this correspondence with the student researcher.

Modifications Required or Reasons for Non-Approval

None 


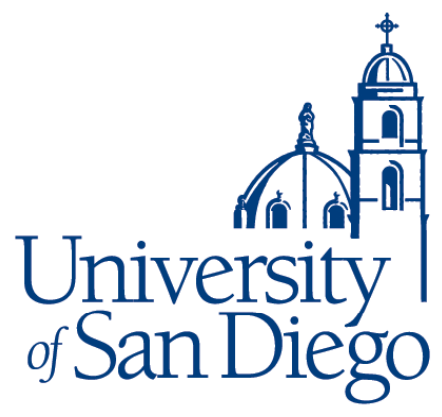

The next deadline for submitting project proposals to the Provost's Office for full review is N/A. You may submit a project proposal for expedited review at any time.

Dr. Thomas R. Herrinton

Administrator, Institutional Review Board

University of San Diego

herrinton@sandiego.edu

5998 Alcalá Park

San Diego, California 92110-2492 